\title{
VOC Slave Trading Strategies on the Madagascar to Cape Slave Route, 1676-1781'
}

\author{
Michael Charles Reidy
}

\section{Introduction}

The island of Madagascar, which is situated in the southwestern reaches of the Indian Ocean, opened its markets to Dutch, French, English and Portuguese slave traders from the late 1630s until the nineteenth century, after interacting with Arab traders for over 500 years. The Dutch East India Company (VOC) systematically established its principal slave route from Madagascar to the Cape of Good Hope from 1676 to 1781 through navigation, diplomacy and trade. The Dutch slave trade - den slavenhandel - from Madagascar to the Cape was developed through the orders and instructions (instructiën) of the VOC's Directors, the Heren XVII. The Heren XVII formulated their instructions in cooperation with the colony's administrators, slave-commissioners (commiesen ${ }^{2}$ ) and ships' officers. Ships' instructions, together with the Heren XVII's 'letters of credential' (credentiale brieven), empowered Company officials to enter into contracts and agreements within the area granted to the VOC in Article 35 of the Company's trade charter by the States General of the Dutch Republic. ${ }^{3}$ The captains and merchants of successive Company slave voyages consulted the instructions ${ }^{4}$ and ships' journals (skeepsjoernalen) of previous voyages - charting latitude and

\footnotetext{
${ }^{1}$ This article was originally presented as a paper entitled "Massavana's Testimony: Processes of Enslavement on the Malagasy Coastline c.1766," at the international workshop "Slavery in the Indian Ocean World," Centre for Concurrences and Postcolonial Studies (Växjö-Kalmar) and International Institute for Social History (IISH, Amsterdam), Kalmar, 9 September 2017, hosted by Hans Hägerdal (University of Linnaeus, Sweden) and Matthias van Rossum (IISH). I would like to thank Hans Hägerdal for providing funds from Linnaeus University and the Crafoord Foundation (Lund, Sweden) to participate in the workshop and Kathrine Sondergaard, Vanessa Smuts and Marthinus van Bart for their valued assistance.

2 The merchant in charge of the VOC slave voyage was called the commies or "commissioner." The English equivalent of commies is "supercargo" or "merchant."

${ }^{3}$ Yvette Ranjeva-Rabetafika, René Baesjou and Natalie Everts, "Of Paper and Men: a note on the Archives of the VOC as a source for the history of Madagascar," Itinerario 24, no. 1 (2000): 45-59, 54n74.

${ }^{4}$ The National Archives in Cape Town (hereafter CA), South Africa, Political Council (Politieke Raad) (C) Series Vol. 2244, "Register op instructies, 1657-1784": 1-139 ["Register of instructions, 1675-1784"] (hereafter CA C 2244) contain a list of ships' "Instructions" (Instructies (Afrikaans)), "Register of papers" (Register van papieren) and crew lists for VOC slave voyages to Madagascar, Anjouan (also called Anzuany, Anjuan and Johanna) and Rio de la Goa from 1656 to 1786. CA C 2361, "Skeeps-en ander joernale": 69-87 and CA C 2243, "Journals kept on board the different ships on their several voyages \& expeditions since the year 1615 till 1793": 3-18, which is an English copy of the Dutch inventory, most likely compiled by Willem Stephanus van Ryneveldt, on Macartney's request, in 1798. Rafael Thiebaut made CA C 2361 available to me.
} 
longitude, reckonings, landfalls as well as encounters at sea and on land - in the execution of their slave voyages and the planning of future expeditions. ${ }^{5}$ This article seeks to explain how the VOC at the Cape developed its slave trading strategies on the northwestern coast of Madagascar from the late seventeenth century through to the landmark voyages of the Leijdsman $(1715)^{6}$ and Brak (1741) of the eighteenth. ${ }^{7}$ These voyages, along with the Herstelling's 1732 voyage to Salida, in west Sumatra, ${ }^{8}$ determined VOC slave trading on the island until the Jachtrust's final voyage closed the slave route from the Cape to Madagascar in 1781.

\section{Secondary literature}

The Heren XVII's instructions, along with the Company's credentiale brieven, are among the earliest expressions of Dutch foreign policy in the South-West Indian Ocean region. The importance of ships' instructions in the VOC slave trade from the Cape to Madagascar has been addressed by James C. Armstrong and Piet Westra in their annotated translation of the Leijdsman's two trade journals of $1715 .^{9}$ Alfred and Guillaume Grandidier, Maurice Boucher, Robert Ross, Stephen Ellis and Solofo Randrianja and Dan

\footnotetext{
${ }^{5}$ Hans Haalmeijer, Pinassen, Fluiten en Galjassen: Zeilschap van de Lage Landen Kustvaart en Grote Vaart, (Alkmaar, Holland: De Aak bv., 2009), 158-59. A ship's speed was determined by timing the movement of a log of wood, tied to a piece of rope, from a given position on the tide to the stern: hence the word "logbook." I am grateful to Graeme Tipp, Volunteer Assistant at the Cutty Sark, Royal Museums Greenwich, for explaining "logbooks" to me. The VOC forbade the use of logs, according to Captain Bligh's report in 1792. Therefore, the entries of the EIC's watch are called logbooks; while the captain's log on VOC voyages is called a dagregister or skeepsjoernaal.

${ }^{6}$ James C. Armstrong and Piet Westra, Slave Trade with Madagascar: The journals of the Cape slaver Leijdsman, 1715 (Cape Town: Africana Publishers, 2006). Westra has translated both of the Leijdsman's trade journals from eighteenth century Dutch to English. ${ }^{7}$ Archives Den Haag (hereafter HA), Netherlands, VOC Series, Access Number 1.04.02, "Inventaris van het archief van de Verenigde Oost-Indische Compagnie (VOC), 1602-1795, Deel I/E.5.b: Overgekomen brieven en papieren uit de Kaap de Goede Hoop aan de Heeren XVII en de kamer Amsterdam" ("Letters and Papers Despatched from the Cape of Good Hope to the Seventeen Lords and the Amsterdam chamber" (1651-1794)), HA vol. 4149 Brak skeepsjoernaal (4 May to 25 December 1741): 241-458 (hereafter "HA 4149, Brak (1741)"). See Alfred and Guillaume Grandidier, Collections des ouvrages anciens concernant Madagascar (COACM) vol.6, "Voyage du besteau De Brak," 1741 (Paris: Comité Madagascar, 1913): 52-196. The Brak's instructie appears in HA vol. 4144, "Instructie meede gegeeven aan de Ovenlede van den Hoeker de Brak gaande na Madagascar" (hereafter "HA 4244, Brak instructie (11 October 1740)"): 128-41. See https://www.nationaalarchief.nl/onderzoeken/archief/1.04.02 for digitized scans of HA VOC 1.04.02 Overgekomen brieven: instructiën, skeepsjoernale and skeepsrollen. The VOC outfitted over fifty slave voyages from the Cape to Madagascar from the 1640s to 1786, including 12 from 1740 to 1781 . This article draws on the TANAP Resolusies (Resolutiën) of the Political Council of the Cape of Good Hope (hereafter C), http://databases.tanap.net/resolusies/ (Retrieved 1 October 2020). See appendix for a complete list of the collections containing ships' instructions and ships' journals at the South African National Archives, in Cape Town, and the Netherlands Nationaal Archief, at Den Haag.

${ }^{8}$ The Herstelling was despatched from Batavia to purchase Malagasy slaves for the Company's gold mines at Salida.

${ }^{9}$ Armstrong and Westra, Slave Trade.
} 
Sleigh and Piet Westra have published lengthy translations of VOC ships' journals and extracts from ships' journals in scholarly articles and books. ${ }^{10}$ The above works spotlight individual slave voyages, or clusters of voyages, but do not explain how these voyages relate to the VOC slave trade to Madagascar as a whole. It is not surprising, therefore, that Westra and his coauthors have failed to notice the repeated use of the Brak's instructions, issued on 11 October 1740, on nearly a dozen Company slave voyages from 1741 to $1781 . .^{11}$

Armstrong has estimated the importation of some 2,820 slaves, out of thirty-three of some forty VOC slave voyages, outfitted at the Cape from 1654 to 1784 , along with terse descriptions of the trade during the VOC era. ${ }^{12}$ His account of the VOC slave trade has been expanded upon by Robert CarlHeinz Shell and Nigel Worden; while Sleigh and Westra's account of slavecommissioner Johan Godfried Krause's three slaving expeditions, on the Neptunus (1760) and Meermin (1762 and 1766), portrays the VOC slave trade to Madagascar as haphazard, rather than strategic. ${ }^{13}$ Yvette Ranjeva-

\footnotetext{
${ }^{10}$ Alfred and Guillaume Grandidier, COACM vol.6, "Voyage du besteau De Brak," 1741: 52-196; Maurice Boucher, "The Voyage of a Cape Slaver in 1742," Historia 24, no. 1 (1979): 50-58; Robert Ross, ed., "The Dutch on the Swahili Coast, 1776-1778: Two Slaving Journals, Part 1," [trade journal of the Zon (2 May 1776 to 25 April 1777)] The International Journal of African Historical Studies 19, no. 2 (Boston University African Studies Centre, 1986): 305-60; and "The Dutch on the Swahili Coast, 1776-1778: Two Slaving Journals, Part 2," [trade journal of the Jachtrust (29 June 1777 to 25 January 1778)], The International Journal of African Historical Studies 19, no. 3 (Boston University African Studies Centre, 1986): 479-506; Stephen Ellis and S. Randrianja, "Les archives de Compagnie néerlandaise des Indes orientales et l'histoire de Madagascar. L'expedition du navire de la Verenigde Oostindische Compagnie (V.O.C.) Le Schuylenburg - Septembre 1752," in I. Rakoto, ed., La route des esclaves (Paris: Harmattan, 2000), 47-73; and, Dan Sleigh and Piet Westra, The Taking of the Slaver Meermin 1766 (Cape Town: Africana Publishers, 2013).

11 See Westra's translation of the Council of Justice's "extract" of the Meermin's instruction from 1766 in Sleigh and Westra, Meermin, 122-23. This extract of the Meermin's instruction is a verbatim copy of a large portion of the Brak's instruction.

12 James C. Armstrong and Nigel A. Worden, "The Slaves, 1652-1795," in Richard Elphick and Hermann Giliomee, eds., The Shaping of South African Society, 1652-1820, $2^{\text {nd }}$ ed. (Cape Town: Maskew Miller Longman, 1989): 109-68, 112. James C. Armstrong, "Madagascar and the Slave Trade in the Seventeenth Century," Omaly Sy Anio (Hier et aujour d'hui) 17-20 (1983-84): 211-32. See also Markus Vink's summary of the VOC slave trade, "'The World's Oldest Trade.' Dutch Slavery and the Slave Trade in the Indian Ocean in the Seventeenth Century," Journal of World History 14, no. 7 (June 2003): 131-77.

${ }^{13}$ Robert C.-H. Shell, Children of Bondage: A Social History of the Slave Society at the Cape of Good Hope, 1652-1838 (Johannesburg: Witwatersrand University Press, 1994), Ch.2 "The Tower of Babel: The Slave Trade and Creolization," 40-65; and Nigel A. Worden, "Indian Ocean Slavery and its demise in the Cape Colony," in Gwyn Campbell, ed., Abolition and its Aftermath in Indian Ocean Africa and Asia (New York: Routledge, 2005), 29-49 and Slavery in Dutch South Africa (Cambridge: Cambridge University Press, 1985). See also Robert C.-H. Shell, ed., From Diaspora to Diorama: A Guide to the Old Slave Lodge (Cape Town: Nagpro, 2013). Nigel A. Worden, "Indian Ocean Slaves in Cape Town, 1695-1807," Journal of Southern African Studies 42, no. 3 (2016): 389-408, 400: Nigel Worden gives an alternative figure of 3,753 for the number of slaves imported at Cape Town (cf. James J. Ravell's unpublished, "The VOC Slave Trade Between Cape Town and Madagascar," (Leiden, 1978)).
} 
Rabetafika, René Baesjou and Natalie Everts explored a number of ways in which the VOC's Overgekomen Brieven en Papieren (letters and papers despatched from the Cape) can be mined for valuable information on the VOC slave trade from Madagascar to the Cape and Batavia during the seventeenth and eighteenth centuries. ${ }^{14}$ Anna Boëseken, Robert Shell and Karel Schoeman have been unable to neatly bridge the VOC's seventeenth century slave trade from the Cape to Madagascar with that of the eighteenth century. ${ }^{15}$ The main shortcoming of the existing literature on the VOC slave trade from the Cape to Madagascar is the absence of analysis between the two main phases of the trade: from the Voorhout to the Leijdsman, 1676-1715; and the Leijdsman to the Jachtrust, 1715-81. Though the VOC slave trade to Madagascar constitutes what Nigel Worden calls a "small proportion of the whole" Indian Ocean slave trade to the Cape, ${ }^{16}$ the VOC instructions and trade journals identify the meeting-point between Company slave traders and other participants on the coast of Madagascar. ${ }^{17}$ Arne Bialuschewski, Stephen Ellis and Jane Hooper have described the political economy of various kingdoms and chiefdoms of Madagascar in relation to European trade in the seventeenth and eighteenth centuries. ${ }^{18}$ Bialuschewski has described how the highly organized and structured markets of northwestern Madagascar regularly supplied enslaved people to the English, Dutch and French after 1638. ${ }^{19}$ Hooper's study expands on the traditional assumptions that Madagascar functioned mainly as a slave market during the European colonial era by describing the significant role the island played, with a heavy weighting on English East India Company (EIC) records, in the sale of rice and beef in the provisioning trade of the greater Indian Ocean.

\footnotetext{
${ }^{14}$ Ranjeva-Rabetafika, Baesjou and Everts, "Of Paper and Men," 47. See also 1n7 and appendix. The authors write, "The instruction of October 1740 marked the beginning of two decades in which the Company concentrated on trading on the western coast." This article is an attempt to show how that strategy came about, as well as demonstrate the importance of the Brak's instructions in the Company's slave trade to Madagascar, through their repeated use, from 1741 to 1781 .

${ }^{15}$ Anna Bōeseken, Slaves and free blacks at the Cape, 1658-1700 (Cape Town: Tafelberg, 1977); Karel Schoeman, Early Slavery at the Cape of Good Hope, 1652-1717 (Pretoria: Protea Book House, 2007) and Portrait of a Slave Society: The Cape of Good Hope, 17171793 (Pretoria: Protea Book House, 2012).

${ }^{16}$ Nigel Worden, "Indian Ocean Slaves," 397.

${ }^{17}$ See also Andrew Alexander, "Negotiation, trade and the rituals of encounter: an examination of the slave trading voyage of De Zon, 1775-1776," Kronos: Journal of Cape History [Cape Town] 33 (November 2007): 84-111. Alexander's "close reading" of the Zon's trade journal limits his study to a microhistory of the Zon's voyage and other related voyages.

${ }^{18}$ Arne Bialuschewski, "Pirates, Slaves, and the Indigenous Population in Madagascar, c.1690-1715," International Journal of African Historical Studies 38, no. 3 (2005), 401-25; Stephen Ellis, "The history of sovereigns in Madagascar: new light from old sources," in Didier Nativel and Faranarina V. Rajaonah, eds., Madagascar revisitée: en voyage avec Françoise Raison-Jourde (Paris: Karthala, 2009): 405-31; and Jane Hooper, Feeding Globalization: Madagascar and the Provisioning Trade, 1600-1800 (Athens: Ohio University Press, 2017).

${ }^{19}$ Bialuschewski, "Pirates," 40.
} 
Nigel Worden has remarked that scholars have increasingly recognised the importance of "Indian Ocean Asian and African slave trading networks" in the shaping of contemporary politics in South Africa's Western Cape region. ${ }^{20}$ Patrick Harries, on the other hand, highlights the importance of eighteenth and nineteenth century slave traffic from Mozambique in the formation of culture among the descendants of slaves in Cape Town and the Western Cape. ${ }^{21}$ Harries has also investigated Cape Town's role in the assistance, and, later, the abolition, of European slave traffic between the South-West Indian Ocean and the Atlantic. Moving away from the concerns of South African historians, Stephen Ellis, Jane Hooper and Rafael Thiebaut have consulted VOC ships' journals to support their conclusions on politics, encounter and commerce at Madagascar. ${ }^{22}$ Hooper and Eltis have demonstrated the relationship between the transatlantic slave trade and the Indian Ocean in their analysis of slave voyages from the Transatlantic Slave Trade Database in 2013. ${ }^{23}$ They estimate that one-fifth of all transatlantic slave voyages during "the early period" (ie. the late seventeenth century) were from ports of embarkation in the South-West Indian Ocean, ${ }^{24}$ and further conclude that the passage between New York and Madagascar, "must have been one of the largest slave trading routes in the history of the world." 25 Gregory O'Malley has noted, in support of this thesis, that slave voyages from Southeast Africa accounted for an estimated 9 percent of Africans carried to

\footnotetext{
${ }^{20}$ Worden, "Indian Ocean Slaves," 405. See also Nigel Worden, "Slavery and amnesia: towards a recovery of Malagasy heritage in representations of Cape slavery," in Ignace Rakoto, ed., L'esclavage à Madagascar: Aspects Historiques et Résurgences

Contemporaires (Antananarivo: Institut de Civilisations - Musée d'Art et d'Archéologie, 1997): 51-63, 54. Worden identifies these two broad phases of the VOC slave trade from the Cape to Madagascar.

${ }^{21}$ Patrick Harries, "Middle Passages of the Southwest Indian Ocean: A Century of Forced Immigration from Africa to the Cape of Good Hope," The Journal of African History 5, no. 2 (July 2014): 173-90 and "Mozambique Island, Cape Town and the Organization of the Slave Trade in the South-West Indian Ocean, c.1797-1807," Journal of Southern African Studies 42, no. 3 (2016): 409-27. See also Pedro Machado, "A Forgotten Corner of the Indian Ocean: Gujarati Merchants, Portuguese India and the Mozambique Slave-Trade, c.1730-1830," in Slavery \& Abolition 24, no. 2 (2003): 17-32 and Ocean of Trade: South Asian Merchants, Africa and the Indian Ocean, c. 1750-1850 (Cambridge: Cambridge University Press, 2014).

22 Jane Hooper, Feeding Globalization; and Rafael Thiebaut, "Traites des esclaves et commerce néerlandais et français á Madagascar (XVIle-XVIIle siécles)," unpublished PhD. Thesis (Sorbonne University Paris and the Free University Amsterdam, 2017); "De Madagascar à Sumatra: une route négrière peu commune. Le voyage du navire Binnenwijzend de la VOC en 1732," Afriques [online] no.6 (21 December 2015): 1-63. URL: http://journals.openedition.org/afriques/1805; and, "The Role of "Brokers" in the Dutch Slave Trade in Madagascar in the Eighteenth Century," in Preben Kaarsholm, Manoel João Ramos and lain Walker, eds., Fluid Networks and Hegemonic Powers in the West Indian Ocean (Lisbon: Centro de Estudos Internacios do Instituto de Lisboa, 2017): 37-64. Thiebaut has made extensive use of Dutch and French ships' journals in his research. ${ }^{23}$ Jane Hooper and David Eltis, "The Indian Ocean in Transatlantic Slavery," Slavery \& Abolition 34, no. 3 (2013): 353-75.

${ }^{24}$ Ibid., 367.

${ }^{25}$ Ibid., 358.
} 
North America from 1671 to $1710,{ }^{26}$ at a time of increased slave transactions at the Cape. ${ }^{27}$ The Cape of Good Hope's geographical position, therefore, placed the port of Cape Town (Table Valley) within the ambit of both transatlantic and trans Indian Ocean slave routes. Richard B. Allen's revision of Alfred and Guillaume Didier and Jean-Marie Filliot's quantification of slave traffic from the ports of East Africa and Madagascar to the Mascarene Islands, along with his description of the Mascarenes role as a staging-post for the slave trade from the mid-eighteenth century, marks the first significant departure from the traditional scholarship on the slave trade in the South-West Indian Ocean region. ${ }^{28}$ Rafael Thiebaut has also improved our understanding of the extent of Mascarene slave traffic on the island of Madagascar by identifying at least 458 French voyages to the island from 1720 to 1769 , though many of these voyages were exclusively engaged in the provisioning trade. ${ }^{29}$ Allen, Eltis, Harries, Hooper, Thiebaut and Worden are all informed by a transnational and interregional approach to slave studies in the Indian Ocean, and their quantitative findings expand upon the work of José Capela, Herbert Klein and Manolo Florentino due to their focus on intra-African slave trading networks in the South-West Indian Ocean. ${ }^{30}$ The Cape of Good Hope was considered the "masterlink of connection between the western and eastern world" ${ }^{31}$ before the appearance of steam and the opening of the Suez Canal. The Cape, therefore, played an integral role in transatlantic forced migrations and slave voyages across the South-West Indian Ocean, and greater Indian Ocean beyond.

\footnotetext{
${ }^{26}$ Gregory E. O'Malley, Final Passages: The Intercolonial Slave Trade of British America, 1619-1807 (Williamsburg, Virginia: University of North Carolina Press, 2014), Figure 2., 110.

${ }^{27}$ Schoeman, Early Slavery, 94.

${ }^{28}$ Richard B. Allen, "A traffic of several nations: the Mauritian slave trade, 1721-1835," in V. Teelock and E.A. Alpers, eds., History, Memory and Identity (Mauritius: University of Mauritius, 2001), 157-77; "The Mascarene Slave-Trade and Labour Migration in the Indian Ocean during the Eighteenth and Nineteenth Centuries," in Gwyn Campbell, ed., The Structure of Slavery in Indian Ocean Africa and Asia (New York: Routledge, 2006), 33-50; "The constant demand of the French: The Mascarene Slave Trade and the World of the Indian Ocean and Atlantic during the Eighteenth and Nineteenth Centuries," Journal of African History 49, no. 1 (2008), 43-73; and, European Slave Trading in the Indian Ocean, 1500-1850 (Athens: Ohio University Press, 2015), 88-89: Allen has considerably revised the count of slave voyages to the Mascarene Islands from 600 to 950 .

${ }^{29}$ Thiebaut, "Traites des esclaves," "Tableau 53: Expédities françaises à Madagascar aux xVIII'e siècle," 482.

${ }^{30}$ José Capela, O Tráfico de Escravos nos Portos de Moçambique, 1733-1904 (Porto: Ediçōes Afrontamento, 2002); Manolo Florentino, Em Costas Negras: Uma história do tráfico de escravos entre a África e o Rio de Janeiro (séculos XVIII e XIX), (São Paulo: Companhia Das Letras, 1997); and, Herbert S. Klein, The Middle Passage: Comparative Studies in the Atlantic Slave Trade (New Jersey: Princeton University Press, 1978).

${ }^{31}$ CA A 455, Dundas-Melville Papers, "Macartney's Description of the Cape colony" (1798).
} 


\section{Ships' instructions and ships' journals ${ }^{32}$}

Captain Woodes Rogers observed that the colonial government at the Cape had sent a slave voyage to Madagascar every other year when he docked the Delicia at Table Bay in 1713. ${ }^{33}$ Rogers, who was commissioned by the English Royal Navy to capture pirate ships off the eastern coast of Madagascar, had ambitions to establish a 'factory' at Madagascar for the exportation of slaves to New York, the West Indies and the Cape. ${ }^{34}$ On 29 November 1797, Willem Stephanus van Ryneveldt, the colony's attorneygeneral (fiscaal), informed the first British governor of the Cape, Earl George Macartney, ${ }^{35}$ that the VOC had sent out a slave expedition every two to three years from the beginning of Dutch rule. Van Ryneveldt, who oversaw the Company's municipal slave workforce, warned Macartney that the colony's grain and wine production would languish, and then totally decay, should he forbid the importation of slaves into the occupied colony. ${ }^{36}$ The governor's personal secretary Sir John Barrow consulted VOC shipping rolls and inventories in the drafting of his unpublished manuscript Sketches of the Political and Commercial History of the Cape of Good Hope (1796): the first major writing to include a comprehensive history of slavery and the slave trade in Dutch South Africa. ${ }^{37}$ Barrow, who supplied Macartney with a list of VOC slave voyages, declared "prohibition of the usual trade" (i.e. the VOC slave trade) to be one of the first changes implemented by the British at the Cape. ${ }^{38}$ The VOC's precise record of shipping rolls (scheepsrollen), ships' instructions and ships' journals, however, provides a unique inventory of at

\footnotetext{
${ }^{32}$ See appendix. The greater portion of VOC trade journals and instructions are available online at: https://www.nationaalarchief.nl/onderzoeken/archief/1.04.02.

${ }_{33}$ David Cordingly, Spanish Gold: Captain Woodes Rogers and the Pirates of the Caribbean (London: Bloomsbury Publishing, 2011), 115.

${ }^{34}$ British Library (BL) India Office Records (hereafter IOR)/D/93 f.511 (Minutes of EIC Directors) and IOR B 154 f.22, Captain Woodes Rogers to Sir Hans Sloane, 7 May 1716, Sloane Collection no. 4044, f. 155.

${ }^{35}$ Lord Macartney (14 May 1737 to 31 May 1806) was governor of the Cape from May 1797 to November 1798. Macartney, like the VOC's administrators, prohibited slave traffic to the east of the Cape in order to protect the EIC's trade charter in the Indian Ocean. This prohibition prevented the outflow of grain to the French at Mauritius during the Napoleonic Wars and discouraged unlicensed trade, private trade and piracy east of the Cape.

${ }^{36} \mathrm{CA}$ Accessions (A) A 455 BP 12 (10), W.S. van Ryneveldt, "Replies to the Questions on the Importation etc. of Slaves into the Colony; Proposed by His Excellency the Earl of Macartney, etc. dated 29 November 1797 (presented to the Cape Archives (CA) by G.W.A. Mears, "the original mss. destroyed by fire")." Willem Stephanus van Ryneveldt (17651812) was the colony's fiscaal from 1795 to 1809. The fiscaal was the Chief of Justice and public prosecutor during the VOC era. The fiscaal, after the secunde (second-incommand), was the third most senior official at the Cape during VOC rule.

${ }^{37}$ Brenthurst Library, Johannesburg, Oppenheimer Collection, MS 61/3, Sir John Barrow, Sketches of the Political and Commercial History of the Cape of Good Hope (1 December 1796) (unpaginated).

$38 \mathrm{lbid}$.
} 
least forty Company slave voyages to Madagascar and East Africa during the VOC era. ${ }^{39}$

The Heren XVII ordered Simon van der $\mathrm{Stel}^{40}$ and his Political Council (Politiecquen Raad) to purchase slaves at Madagascar for the Cape; and to send a number of those slaves to Batavia (Jakarta), on a "yearly" basis, before the Westerwijk's voyage, in $1685 .{ }^{41}$ Copies of the ship's instructions were kept - along with trade journals from earlier expeditions, the Heren XVII's mandate (reglement) dated 22 November 1685,42 cargo inventories and a 'register of papers' (relevant to the voyage) - in the master's cabin of the Company's ship ${ }^{43}$ and at the office of the secretary of the Political Council at the Castle of Good Hope. Ships' captains took charge of the voyage at sea; and slave-commissioners, who were usually junior merchants, conducted the trade commission on land. The captain's diary (dagregister) documented the expedition's outgoing and incoming voyages; while the slave-commissioner's ship's journal was a detailed account of the party's trade commission. ${ }^{44}$ Cooperation between the ship's captain, senior officers and slavecommissioners determined the success of a slave voyage; and the leaders of VOC slave expeditions made collective decisions, in consultation with the ship's instructions, on their ship's council or skeepsraad. ${ }^{45}$ In 1663, for example, the commander of the Cape of Good Hope Zacharias Wagenaer ${ }^{46}$ blamed the failure of the VOC's early slave voyages on the lack of cooperation between captains and slave-commissioners - a slight on Jan van Riebeeck, the first commander of the Cape. ${ }^{47}$ Charles Barrington, the supercargo who had chartered the Danish West India Company ship

\footnotetext{
${ }^{39}$ CA C 2361 and CA C 2243. VOC slave expeditions returned to the Cape via Rio de la Goa and, later, Terra de Natal (the Natal coast), from the mid-seventeenth century. The Company despatched slave voyages to Zanzibar, Pemba and Ibo after 1770.

40 Simon van der Stel (14 October 1639 to 24 June 1712) was appointed commander of the Cape of Good Hope in 1679. Van der Stel was appointed first governor of the Cape in 1691, and retired in 1699. He was succeeded by his son Willem Adriaan van der Stel. Simon and Willem Adriaan were of mixed Indian and Dutch descent.

${ }^{41}$ Pieter van Dam, Beschryvinge van de Oostindische Compagnie, XLVII, "orders van de XVII voor den slavenhandel," Bijlage II, (Amsterdam, 1701): 668-70. Van Dam was an advocate (avocaat) of the VOC's Amsterdam chamber. Van Dam's "Description of the East India Company" is a history of the VOC from 1602 to 1701.

42 The Heren XVII's reglement or "regulation" stipulated how slaves were to be managed and treated during the slave trade.

${ }^{43}$ Frequently called "het permanent schip" (the "permanent ship") in the records. The Heren XVII supplied the settlement with a ship for the slave trade from the time of Jan van Riebeeck. The Company's ship was used to carry freight between the settlement's ports during the off season.

${ }^{44}$ François Renier Duminy was both slave-commissioner and captain of the Meermin (a different ship from the Meermin of 1766) from 1781 to 1786.

45 The VOC made the keeping of minutes or "resolutions" by the ship's council mandatory after 1741.

${ }^{46}$ Zacharias Wagenaer (10 May 1614 to 12 October 1668) was the second commander of the Cape from 6 May 1662 to 27 September 1666.

47 Jan Anthoniszoon van Riebeeck (21 April 1619 to 18 January 1677) was the first commander of the Dutch settlement of the Cape of Good Hope from 6 April 1652 to 1662.
} 
Grevinden af Laurvigen in 1737, proclaimed that the company's charter and ship's instructions had invested him with authority over the slaver and its English and Danish crew, much to the chagrin of the Danish captain Holst who told him, "I am not your servant!" 48

When the Dutch warship the Amersfoort seized 250 slaves from a Portuguese caravel off the coast of Angola in 1658, the captors did not know how to take command of the vessel because the ship's instructions were missing from the captain's cabin. The VOC adopted the instructions issued to Dutch West India Company (WIC) slavers ("Instruction for the captains in the service of the West Indian Company's slave trade") in 1675 on its slave trade from Madagascar to Batavia, Salida and the Cape. ${ }^{49}$ In 1685, advocate Pieter van Dam, who had studied WIC transatlantic slave voyages from the $1620 \mathrm{~s}$ and 1630s, issued further instructions on the slave trade from the Cape to Madagascar. ${ }^{50}$ The use of WIC ships' instructions by the VOC, therefore, connects the transatlantic slave trade with the slave trade of the South-West Indian Ocean (Cape Town and Mauritius) and greater Indian Ocean (Ceylon, Salida and Batavia). ${ }^{51}$ Van Dam's instructions were the basis of nearly all seventeenth century slave voyages despatched from the Cape; and certain standard instructions were incorporated into the Brak's seminal instructions of 1740. The Company Directors imparted Company policies on navigation and the management of ships' personnel and slaves, as well as trade policies, with their instructien. The Brak's instructions were the product of forty years of VOC slave voyages to Madagascar (1676 to 1715) and were included, in whole or in part, on Company voyages until 1781. Ships' instructions were presented to ships' captains and slave-commissioners prior to their departure for Madagascar by either the governor, secunde or the secretary at the secretary's office at the Castle of Good Hope. The slave-commissioner Hendrik Frappé s2 $^{2}$ described the importance of the authority of the

\footnotetext{
${ }^{48}$ Danish National Archive (DNA) (Rigsarkivet) 446, "Het Vestindisk-Guineisk kompagni, Charles Barrington," 218 1737-1742 (hereafter, "DNA 446, Charles Barrington, loose papers") and "Barrington's trade journals, charter party and ship logbooks," 220, no. 2 1737-1738, "Logbook no. 1," 46. The Danes later mutinied against the English, and threw Barrington down the ship's hatch. See also Maurice Boucher, "An Unexpected visitor: Charles Barrington at the Cape in 1737," South African Historical Journal 13, no. 1 (University of South Africa: Pretoria, 1981): 20-35.

${ }^{49}$ Armstrong and Westra, Slave Trade, 31n82: "Instructie voor de schippers, die in dienst van de West-Indische Compagnie op de slaefhandel vorende" (1675).

${ }^{50}$ Van Dam, Beschryvinge, 668.

${ }^{51}$ Schoeman, Slave Society, 96-97. Schoeman explains how the WIC slave trade was of far greater size than the VOC Cape to Madagascar slave trade, with the Company ferrying at least 330,000 slaves to Dutch possessions across the Atlantic during the eighteenth century. The WIC outfitted at least 383 slave voyages from 1674 to 1740 , and carried at least 30,000 enslaved Africans from Africa to the New World during the decade 1720-29. ${ }^{52}$ Armstrong and Westra, Slave Trade, 135n4. Hendrik Frappé (c.1678-1747) was born in Amsterdam, and served the Company in Batavia before his arrival at the Cape in 1706. Frappé was appointed slave-commissioner of Leijdsman in 1715 and was later appointed superintendent of the Slave Lodge from 1717-33. In 1734, he returned to Holland with his
} 
Leijdsman's instructions in his journal entry at Anjouan (Nzwani) dated 1 September 1715:

Having deliberated and considered the matter, we decided not to make any payment for the aforementioned debentures [owed to an Arab merchant by officers of the Schoonhouwen (c.1711)] because we knew nothing about them and it was not authorized. It could not have been expected of us, because no subject may act on own authority, and in addition we had our honoured instruction according to which we should act [emphasis added]. ${ }^{53}$

Otto Lüder Hemmy ${ }^{54}$ referred to the "high orders," and, therefore, gravity of the Honourable Company Directors' instructions during the Brak's first voyage to the northwest coast of Madagascar in $1741 .{ }^{55}$ When the Meermin foundered at Soetendaals Valley, near Cape Agulhas, after a shipboard revolt in 1766, the Cape Council of Justice (CJ), or Raad van Justitie, found the ship's captain Gerrit Christoffel Müller guilty of abandoning his command, having leapt overboard with the Meermin's papers tied around his waist. ${ }^{56}$ Müller vehemently denied the charges of carelessness, neglect of duty and disobeying of instructions brought against him. He had considered rowing to shore on the ship's pinnace, but refrained from doing so, understanding the seriousness of abandoning his command. ${ }^{57}$ Müller testified that the third mate Daniel Carel Gulik had not seen the instructions, though Gulik testified that he had asked Müller to show them to him. ${ }^{58}$ Müller and Gulik were stripped of rank, dismissed from the Company and expelled from the colony for neglecting their instructions and for the loss of the Meermin and some thirty slaves and other Company property. Pieter Knollendam, the Leijdsman's

\footnotetext{
family and, in 1743, he came back to the Cape as a free burgher. In 1744, he was appointed bookkeeper of the Company's butchery.

53 Ibid. Hendrik Frappé's trade journal for the Leijdsman, Sunday 1 September 1715, 8587. The Leijdsman's instructions were issued on Tuesday 18 June 1715. The expedition set sail on Thursday June 27 and returned to Table Bay on Thursday 21 November 1715. The slaves were disembarked on Friday 22 November 1715.

${ }^{54}$ D.W. Kruger and C.J. Beyers, eds., Dictionary of South African Biography (Cape Town: Tafelberg, 1977), 385. Otto Lüder Hemmy was born in Bremen in May 1710 and died at Cape Town on 29 January 1777. Hemmy occupied a number of posts in the upper echelons of VOC officialdom at the Cape. He presided over the Meermin's trial in August 1766. Hemmy became a member of the Political Council in 1769, after being appointed senior merchant at the Cape. He was promoted to the office of secunde in 1773, putting him in charge of the reception, management and provisioning of vessels calling at the Cape, especially French slavers and the VOC return-fleets. He spent his retirement on his large wine estate, Alphen, in Constantia, Cape Town. Hemmy's four VOC slave voyages on the Brak from 1741 to 1744 are omitted from the Dictionary of South African Biography. ${ }^{55}$ HA 4149, Brak (1741), Thursday 28 September 1741, 390.

${ }^{56}$ Sleigh and Westra, Meermin, 83. See also 149n61: Gerrit Müller was from Diepsteede in the German duchy of Hanover. He was married to Magdalena, daughter of Jan van Smittenberg and his free black wife, Helena Bakker van de Caab, on 20 November 1763. ${ }^{57}$ Michael Charles Reidy, "Book review of Dan Sleigh and Piet Westra's The Taking of the Slaver Meermin, 1766," (2013), Bulletin of the National Library of South Africa [Cape Town] 68, no. 1 (June 2014): 119-22, 120.

58 Sleigh and Westra, Meermin, 120.
} 
captain, told Henrik Frappé and Willem van der Lint that he had not received the journals of the previous voyages from the secretary of the Political Council prior to the expedition's departure for Madagascar, which would have compromised his command should an incident have occurred during the voyage. ${ }^{59}$ The EIC, like the VOC, considered the preservation of the ship's "logg [sic] Book" to be of utmost importance. Both Captain John Balchen of the Onslow (1740) and Stephen Cobham of the Edgebaston (1741) were instructed to keep their logbooks and diaries, as expressed by the clerk, in "a Proper Place," have them copied by an officer and "to take care, That this Book be delivered, together with your own and the Chief-mate's Original Journals to the said Honourable Court, at your return to England." 60

The Cape's first slave-commissioner, sent to the Kingdom of Ardra (in Benin) on the Hasselt in 1658, was instructed by the Heren XVII to keep a "pertinent journal" (pertinent joernaal) of his expedition. ${ }^{61} \mathrm{He}$ was ordered to draft three copies of the journal after the voyage: for the Directors in Amsterdam; the Batavian colonial government; and the secretary of the Political Council at the Castle of Good Hope. Ross notes that three attested copies of the ship's journal were despatched from the Cape to the Netherlands: for the Heren XVII; the Amsterdam chamber; and the VOC's equipage master. ${ }^{62}$ The dagregisters or skeepsjoernalen deposited at the Amsterdam chamber are the only VOC trade journals to survive the clear-out of the Company's Amsterdam archives during the late nineteenth century. The fiscaal kept records of the admission of slaves from Company voyages at the Cape, but these records, sent to the Netherlands during Dutch rule, are now lost. The EIC Directors obliged Captain George Bagwell of the Hertford to keep "an exact Diary" of all his activities at Iongoeloe (Young Owl), on the northwest coast of Madagascar, in his instructions dated 26 October 1730. Bagwell was instructed, as conveyed to him by Josiah Childs, to enter, "therein a particular Account of every days Transactions, together with a Narration of your treating with the Kings and People of the said Island and the Presents you may be obliged to make, with the Reasons delivered to the Deputy Governour [sic] and Council at Fort Marlborough aforesaid, but keep the original and deliver the same to us on your return," along with accountant

\footnotetext{
${ }^{59}$ Armstrong and Westra, Slave Trade, 49-50. On 18 June 1715, Frappé and his assistant van der Lint were perplexed when Knollendom claimed that he had not received the copybooks of the recent slave voyages which the ship's instructions had necessitated him to study. The party were forced to determine the prices of slaves on the advice of Malagasy interpreters.

${ }^{60}$ IOR Maritime Series (hereafter MAR)/D/164C, Onslow (1740), logbook frontispiece signed by Captain Balchen and EIC Secretary, Josiah Childs, 19 November 1740. ${ }^{61}$ Pieter van Dam, Beschryvinge. See also Andre Martinus van Rensburg, "The secret modus operandi used to obtain slaves from Guinea for the Cape: the ship Hasselt, 1658," Familia 38, no. 2 (2001): 78-92; Ranjeva-Rabetafika, Baesjou and Everts, "Of Paper and Men" (see 1n3); and Ross, "Two Trading Journals, Part 1 [the Zon (1776-77)]," 307. 62 lbid. The equipage master was responsible for inspecting ships and ships' crews in the harbour at Table Bay, in Cape town. The equipage master also settled the wages of sailors, living and dead.
} 
William Oaker's ledger of costs incurred during the voyage. ${ }^{63}$ The trade journal was both a report and a record of the slave voyage and slave trade: to be consulted by the Directors in the Netherlands; the colonial authorities at the Cape; and officers who would be engaged in future slave voyages. It is, therefore, not surprising that the VOC slave-commissioner Otto Hemmy asked the king of Boeny to write a letter to the Heren XVII to explain why the king had not supplied him with the number of slaves he had requested of him in $1741 .{ }^{64}$

${ }^{63}$ IOR/MAR/B/106ff., "Orders and Instructions Given by the Court of Directors of the United Company of Merchants of England Trading to the East Indies To Captain George Bagwell, Mr Richard Taylor and Mr William Oaker," (hereafter "Hertford, Instructions (1730)") 26 October 1730, 19.

${ }^{64}$ HA 4149, Brak (1741), 22 September 1741, 415: Otto Hemmy had Maheyningerivo, king "of the northern part of the Island Madagascar" ("van't noordegedeelte op 't Eyland Madagascar"), write a disclaimer addressed "at the Dutch factory at Boeny" ("int hollands factory op Boheenna de 29 Oct:1741") to the Heeren XVII stating that the king provided Hemmy with "no more than a number of 60 'lusty' slaves" ("niet meer als een getal 60 flux Lyfeyngenen"). 


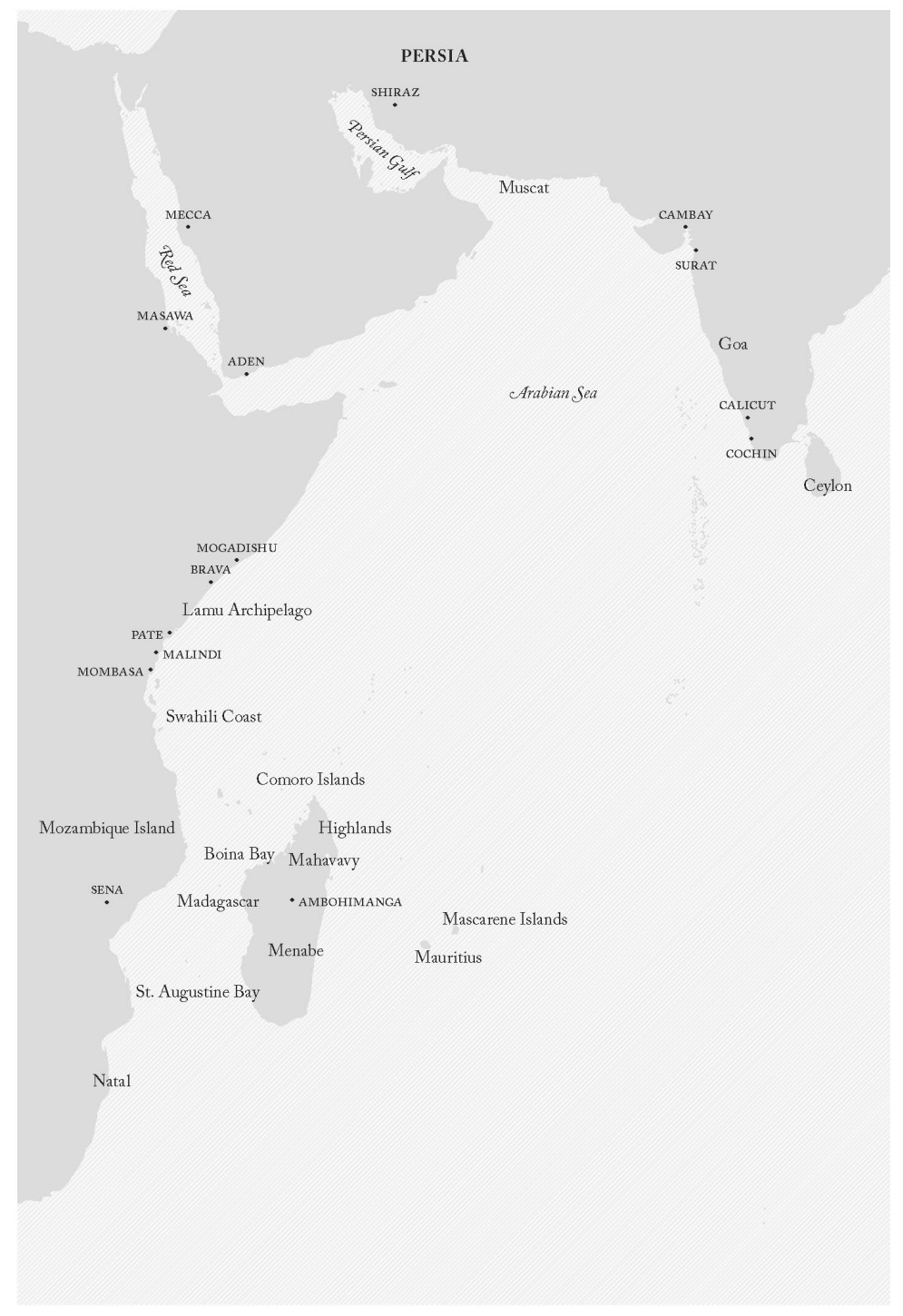

Map 1. The western Indian Ocean World 


\section{The slave route from the Cape of Good Hope to Madagascar, 1676-1781}

The VOC slave trade to the Cape was confined to points of embarkation along its primary slave route from Mauritius, Madagascar, Anjouan and Rio de la Goa Bay (Maputo) from the time of ' $t$ Waterhoen's slave voyage, in 1663, until the time the Dutch abandoned their Mauritian outpost in 1715. The Company's ships usually set sail for Madagascar in May or June (late spring $)^{65}$, purchased slaves on the island during the winter months; then harnessed the southern hemisphere's summer monsoon winds from Madagascar in November, stopping at the Comorian island of Anjouan for provisions, or Rio de la Goa, on the southeastern coast of Africa, for more slaves, before returning to the Cape. These slave expeditions stopped at Mauritius for "a variety of necessary materials and provisions," for example the Westerwijk (1685), before proceeding to Madagascar for slaves. ${ }^{66}$ Mauritius was also a convenient refreshment stop for VOC ships carrying slaves from Madagascar to Batavia between 1663 and 1715. The Company slave trade was confined to Rio de la Goa from 1721 to 1731, but the VOC re-established the slave route from the Cape to Madagascar with the Brak in 1741. Company-sponsored slave voyages later called at Madagascar and Anjouan, then proceeded to the ports of East Africa, from Malindi, on the northern coast, to the Natal coast, in the south, from 1776 to 1786.

European slave traders were supplied rice, cattle and slaves in exchange for Spanish reals, firearms, gunpowder, flints, beads and cloth by the Sakalava (on the northwestern coast), Merina (in the central highlands), Betsimisaraka (on the eastern and northeastern coastlines) and other small kingdoms at Madagascar from 1596 to 1810 . King Tsimenata ousted the Islamic Antalaotra merchant community ${ }^{67}$ - who purchased 2,000 to 5,000 slaves a year at Madagascar - from Mazalagem in 1685, thus asserting his dominance over the northwestern coastal region of Boeny. ${ }^{68}$ Stephen Ellis and Jane Hooper have described how the Sakalava kings secured further control of the slave trade on the northwestern side of the island through marriages to prominent Islamized and Arabic trading families from the Swahili coast and Oman before the arrival of the English, Dutch and French in the 1630s ${ }^{69}$ The Sakalava expanded their interests to the east coast when King Tokaf's senior

\footnotetext{
${ }^{65}$ The direct journey from Madagascar to the Cape took about a month (five to seven weeks).

${ }^{66}$ C 17, Friday 5 October 1685 (retrieved 1 October 2020), 75-78.

${ }^{67}$ This community had slave trading links with the Comoros, Swahili coast and Arabian peninsula.

${ }^{68}$ Armstrong and Westra, Slave Trade, 11; and Thomas Vernet, "Slave trade and slavery on the Swahili coast (1500-1750)," in B.A. Mirzai, I.M. Montana and P. Lovejoy, eds., Slavery, Islam and Diaspora, (African World Press, 2009), 60.

${ }^{69}$ Stephen Ellis, "The history of sovereigns," 418. See also Jane Hooper, Feeding globalisation, 74. Hooper attributes Sakalava influence to tributary relationships with other communities; intermarriage between powerful families; and kinship ties between the Sakalava and various military, religious and political leaders.
} 
advisor, Ratsimilaho, on the claim of taking back ancestral lands, formed the Betsimisaraka confederation in $1716 .^{70}$ The leaders of the Dutch voyages of the Tamboer (1694) and Soldaat (1696) reported that the rulers of Mazalagem were of Arab origin, though the Sakalava have been identified as distinctively Malagasy. ${ }^{71}$ Otto Hemmy wrote in 1741 that King Maheyningerivo honoured the presence of European slave traders with Portuguese, English, French, Dutch and Danish flags at his palace in Maravoay. ${ }^{72}$ St. Augustin's Bay, Toliara and Bombetoka Bay were the island's prominent export markets for slaves at this time. French, English, ${ }^{73}$ Arabs and sometimes Dutch (as in the voyages of the Neptunus (1760) and the Meermin (1762-63)) also traded on the eastern coast of the island from Cape Sainte-Marie, situated at the southernmost point of the island, to Antongil Bay, in the north. ${ }^{74}$

\section{The Cape of Good Hope and the Madagascar slave trade, 1638-1710}

Adriaan van der Stel, the first Dutch commander of Mauritius, sent the Welsing and several other vessels on half a dozen slave trading expeditions from Mauritius to Antongil Bay (on the northeastern coast of Madagascar), and on to Batavia, from 1638 to $1645 .{ }^{75}$ Van der Stel signed a treaty with the Portuguese which limited Dutch activity from the ports of Southeast Africa to Rio de la Goa after $1641 .{ }^{76}$ Early VOC-sponsored slave voyages from the Cape to Madagascar stopped at Mauritius for food, water and wood, from 1663 to 1715. Adriaan van der Stel's son, Simon, was appointed commander of the Cape in 1679. Simon van der Stel and his son, Willem Adriaan, firmly

\footnotetext{
${ }^{70}$ Bialuschewski, "Pirates," 423; Ellis, "Sovereigns," 425; and, Hooper, Feeding

Globalization, 84. Bialuschewski, 424, states: "Prior to 1724 the ports of the east coast had been virtually cut off from colonial markets, as there were few if any vessels from slave vessels." At least fourteen English slavers stopped at the Cape en route from Madagascar to the North American colonies and the West Indies from 1714 to 1723, making Bialuschewski's claim untenable. The Betsimisaraka confederation disintegrated upon Ratsimilaho's death, in 1750.

${ }^{71}$ Armstrong, "Madagascar," 215.

72 HA 4149, Brak (1741), Tuesday 21 August 1741, 355.

${ }^{73}$ Royal Museums Greenwich, Caird Library, London, LUB/39/28, Basil Lubbock "List of East India Company Ships." Lubbock documents at least eighteen EIC voyages that called at The EIC sent at Madagascar from 1732 to 1764.

74 Thiebaut, "Traite des esclaves," 156. The French conducted 134 slave voyages on the east coast of the island and 33 on the west coast; while the Dutch conducted 19 voyages on the east coast and 39 on the west coast.

${ }^{75}$ Pier M. Larson, "Enslaved Malagasy and 'Le Travail de la Parole' in the PreRevolutionary Mascarenes," Journal of African History 48, no. 3 (2007), 459 and Armstrong, "Madagascar," 230. Larson provides 1638 as the date of the first of these voyages. Adriaan van der Stel was the commander of the Dutch settlement of Mauritius from 1640 to 1645. His grandson, Willem Adriaan van der Stel (24 August 1664 to 11 November 1733), was governor of the Cape from 1699 to 1707. See Anna Bōeseken, Slaves and free blacks, on the van der Stels and their activity as agents for English slave traders at the Cape from the c.1679 to 1707.

${ }^{76}$ Schoeman, Early Slavery, 11; and Edward A. Alpers, "The French Slave Trade in East Africa (1721-1810)," Cahiers d'études africaines 10, no. 37 (1970), 86. Alpers writes that Portuguese Royal decrees of 8 February 1711 and 5 October 1715 forbade foreign traders from trading at Portuguese possessions.
} 
established the VOC's slave trade to Madagascar by outfitting at least 16 slave voyages between 1679 and 1707. ${ }^{77}$ The van der Stels forged a small dynastic empire rooted in slave importation from Madagascar to Batavia, Salida and the Cape, through their patronage of the VOC slave trade and the private sale of slaves as agents for English slave traders at the Cape. ${ }^{78}$ The slaves purchased by the VOC at Madagascar were employed on the Company's fortifications, garrison, roadworks, docks and Company Gardens. Slaves were also employed in the homes of VOC officials and sold to the colony's free burghers as labourers on their grain, wine and stock farms. VOC slave trading in the South-West Indian Ocean began in earnest, however, when the Heren XVII commissioned Hubert Hugo to explore Madagascar, the Comoros Islands and Rio de la Goa on the Boogh and Pijl in 1672. Hugo advised the Directors that the northwestern coast of Madagascar was most suitable for slave trading. ${ }^{79}$ The separation of VOC and WIC slave trading interests was established after the Hasselt's voyage to Popo in 1658, though several requests were made to the Heren XVII for the purchase of slaves west of the Cape until the early 1730s. The VOC, however, recognised Madagascar's potential as a supplier of slaves for the Cape and Batavia when a Dutch warship captured an English slaver with a cargo of 182 slaves, from Mazalagem, in $1672 .{ }^{80}$ The Heren XVII thereafter instructed the Cape administration to purchase slaves from the northwestern coast of Madagascar to supplement the settlement's supply of slaves from the VOC's return-fleets.

The Voorhout opened the VOC's slave route from the Cape to Madagascar with a lading of 279 slaves from Mazalagem and Maningare River, ${ }^{81}$ near the bays of Boina (Lahifotsy's River) and Bombetoka, in 1676. Pieter van Dam issued the Hasselt's instructions, which had been drafted for use in West Africa in 1658, for both the Westerwijk (1685) and Jambij's (1686) expeditions to Madagascar. ${ }^{82}$ The Commander and his council consulted the logbook of the English Captain Edwards, who was transporting slaves from Mozambique and Malindi to Boston and St. Lawrence in 1675. Slavecommissioner Abraham van de Bougaard consulted the instructions of the English slaver the Elizabeth, which was captured by a Dutch warship near Anjouan in 1678, prior to the Soldaat's expedition to St. Augustin's Bay and

\footnotetext{
77 The Voorhout (1676 and 1677), Hassenbergh (for Salida, 1677), Elizabeth (for Salida, 1678), Hoogergeest (for Salida, 1681), Sillida (for Salida, 1682), Baaren (1685), Jambij (1686), Tamboer (1694), Standvastigheid (despatched from Batavia, 1695), Soldaat (1696 and 1697), Peter \& Paul (1699), Noordgouw (1701 and 1702) and Ter Aa (1706). ${ }^{78}$ Willem Adriaan van der Stel was expelled from the Cape in 1707 on charges of corruption and misuse of public office. Amongst numerous charges of corruption, the wayward governor employed Company slaves on his wine estate Vergelegen, 50 kilometres east of Cape Town.

79 Schoeman, Early Slavery, 111.

${ }^{80}$ Armstrong and Westra, Slave Trade, 11.

${ }^{81}$ Maningare, known as "New Mazalagem" or "New Massaly," was situated near Boina Bay or Lahifotsy's River. Bombetoka Bay, to the north of Boina Bay, was situated on the river mouth of the Betsiboka estuary, and was called "Old Mazalagem.

${ }^{82}$ Van Dam, Beschryvinge, 668-70.
} 
Toliara, in $1696 .{ }^{83}$ The leaders of the slave voyages of the Sillida and Eemlant were issued with "the Journals of the Elisabeth and other ships despatched in the trade," as well as instructions, nautical charts and "course directions" in January $1682 .{ }^{84}$ Simon van der Stel and his council made two Dutch copies, as well as an English copy, of a portion of the Phillip's logbook, a New York slaver which docked at Table Bay with a human cargo of 130 slaves from St. Augustin's Bay and Boina Bay, in December 1682. ${ }^{85}$ Simon van der Stel questioned Captain James Barry on the geography of the "west side" of the island, his trade goods and any "accurate descriptions from his journal." 86 Van der Stel purchased copies of Barry's logbook for "water-vats, sailing equipment and water-pumps" and made copies of "daily entries" ("daeglijxce aanteekiningh") of the ship's course and trade dealings on the northwest coast of Madagascar. The English captain reluctantly sold van der Stel two slaves whom the governor intended to employ as translators during the voyages of the Bharen (1685), Westerwijk and Jambij. ${ }^{87}$ While Captain Barry had recommended the use of guns, gunpowder, flints and gold coin in exchange for slaves, ${ }^{88}$ the supercargo of the EIC's Caesar informed Simon van der Stel in February 1687 that Mexican silver was in "high demand" there. ${ }^{89}$ Van der Stel and his council also consulted the Loyal Merchant's papers and the instructions of the Harwich, ${ }^{90}$ in 1698, before dispatching the Peter \& Paul (1699) and the Noordgouw (1701) for Madagascar. VOC officials at the Cape made use of their own journals, instructions and maps after 1700. The VOC, however, provided the leaders of slave voyages with English maps of Madagascar" (ie. add "of Madagascar") until 1786.

\section{The VOC slave trade to the Cape, 1715-1781}

Abraham Cranendonk, the colony's second-in-command, and "chief administrator of the slave trade," requested that the slave-commissioners of the Leijsdman consult the cargo manifests of the Noordgouw (1701) and Ter $A a$ (1705 and 1707) for the stocking and provisioning of their voyage on 21

\footnotetext{
${ }^{83}$ St. Augustin's bay, which is situated on the mouth of the Onilahy river, is 35 kilometres south of Toliara, which is situated on the southwestern coast of the island.

${ }^{84}$ CA C 325, VOC Directors (Amsterdam chamber) to Simon van der Stel and the Political Council (Cape of Good Hope), 1 January 1682, 7.

${ }^{85}$ Armstrong, "Madagascar," 200; see also, HA vol. 4018, "Extract úÿt seeker Engelse dagregister gehoúden bÿ James Barree supercargo: op 't Engelse schip de fillip," 2 April 1682 (hereafter, "HA 4018, Phillip (1682)"): 174-95. The Phillip may have belonged to prolific New York slave trader Frederick Phillipse.

${ }^{86} \mathrm{C}$ 16, 13 December 1682, 42-44. The Philip left Madagascar on 12 April 1682 and arrived at Table Bay, under Captain James Barry, on 22 October 1682. See also CA C 325 , Simon van der Stel and the Political Council to the VOC Directors, 1 June 1682, 7681.

${ }^{87}$ Bōeseken, Slaves and freeblacks, 77.

${ }^{88}$ CA C 325, 77-78.

${ }^{89} \mathrm{C} 18$, Monday 10 February $1687,112-15$.

90 HA 1639, "Cabo de Goede Hoop a 1700," Letter from Adriaan van der Stel (governor of the Cape) and Willem van Outhoorn (governor-general of Batavia), 22 March 1700: 37-38.
} 
May 1715. ${ }^{91}$ Governor Maurits Pasques de Chavonnes and his council deliberated on the use of hired labour at the Cape two years later, and concluded that slave labour was cheaper than hired labour because "a herdsman, mason, wagon-driver or workman's apprentice" sold for twice the price of an unskilled slave. ${ }^{92}$ The colonial administration's decision to continue to use slave labour at the Cape prompted the colony's free burghers to petition the government for a license to import slaves into the colony in 1719 , but their request was refused..$^{93}$ The Barneveldt's voyage from Batavia to Madagascar, and on to the Cape, was the last Company slave voyage between Madagascar and the Cape until the Brak's 1741 voyage. ${ }^{94}$ The VOC sent the Barneveldt on a reconnaissance voyage along the southeastern coast of Africa, yielding the 'Barneveldt Map' of Madagascar, in 1719. ${ }^{95}$ The Company obtained slaves, however, from Rio de la Goa on snows and galjoots from 1723 to 1731, with the help of English logbooks during the early 1720s. The governor and council petitioned the Heren XVII in April 1739 for a ship for the slave trade to Madagascar, "where the slaves are beyond all doubt preferable to those to be found at Rio de la Goa." 96

English merchants capitalized on parliamentary lobbying that led to the deregulation of the Royal African Company's (RAC) monopoly of the slave trade in the early 1690s ${ }^{97}$ The deregulation of the English slave trade precipitated a surge of English and American slave traffic at Madagascar and, to a lesser degree, Mozambique - with "interlopers" (enterlopen) importing Malagasy slaves to the Cape, New York, Boston and the West Indies until the turn of the eighteenth century. ${ }^{98}$ The establishment of the Bank of England in 1694 created a tide of 'bonded' capital which challenged land-based capital and the RAC's royal prerogative. ${ }^{99}$ The EIC later issued

\footnotetext{
${ }^{91}$ Armstrong and Westra, Slave Trade, 15 and C 33, Noon Tuesday 21 May 1715, 68-70. The Political Council's resolutiën refer to Cranendonk as the "hoofdadministrateur tot den handel van slaven."

${ }^{92}$ Schoeman, Early Slavery, 235. Chavonnes was governor of the Cape from 1714 to 1721.

${ }_{93}$ Worden, Slavery in Dutch South Africa, 42. See also C 89, Tuesday 25 March 1732, 72 90.

${ }^{94}$ Robert C.-H. Shell, "The Twinning of Maputo and Cape Town: The Early Mozambican Slave Trade to the Slave Lodge: 1677-1731," Quarterly Bulletin of the National Library of South Africa [Cape Town] 55, no. 3 (2001): 114-20, 115.

${ }^{95}$ CA C 2344, 12.

${ }^{96}$ Karel Schoeman, Slave Society, 126, (cf. C 110, 28 April 1739); and 124, in 1739 the Political Council described slaves from Delagoa Bay slaves as "murderous by nature and also very much inclined to thieving and absconding."

${ }^{97}$ The Royal Africa Company was established under the Royal prerogative of King Charles II, with the support of the English aristocracy, in 1660.

${ }_{98}$ William Pettigrew, Freedom's Debt: The Royal African Company and the Politics of the Atlantic Slave Trade, 1672-1752 (Williamsburg, Virginia: University of North Carolina Press, 2013). Pettigrew calls the lobbyists 'separate traders.' See Maurice Boucher, "The Cape and foreign shipping, 1714-1723," South African Historical Journal 6, no. 1 (November 1974): 3-29.

${ }^{99}$ Niall Ferguson, The Ascent of Money: A Financial History of the World (London: Penguin Books, 2009), 90. The establishment of the Bank of England reflects the change from land-
} 
licenses at 10 percent interest in the cargo, which permitted the RAC, the South Sea Company (SSC) ${ }^{100}$ and private merchant firms to trade at Madagascar from 1715 to $1723 .{ }^{101}$ The SSC, established in the Corporation of the City of London in 1711, was awarded the Spanish asiento to import slaves to Rio de la Plata at the Treaty of Utrecht in 1713, which enabled its directors to charter EIC vessels for the slave trade to Madagascar. The presence of English slave traders in the South-West Indian Ocean provided the VOC at the Cape with information on the Malagasy slave trade and a steady supply of slaves from the 1680 s to 1710 . English pirates migrated from the Caribbean to the South-West Indian Ocean region in the 1680s, trading in provisions and slaves between Matatan and Antongil Bay before the East India Act outlawed piracy in 1699. The act led to the granting of Royal commissions to the Royal Navy and privateers, like the Delicia, to seize pirate ships after $1700 .{ }^{102}$ British Parliamentary legislation did not seem to accomplish much in the way of suppressing piracy, since Willem Adriaan van der Stel, French seafarer Godefroy de la Merveille and Captain Woodes Rogers reported that pirates were still active on the east coast of Madagascar during the first decade of the eighteenth century. ${ }^{103}$ Parliamentary lobbying saw another rise in private English trade to Madagascar from 1715 to 1722 which, again, fomented piracy in the region. Decisive English and French naval action, coupled with Betsimisaraka military action, however, greatly reduced the threat of piracy on the eastern coast of Madagascar after 1731. Otto Hemmy did not call at Morondava and Iongoeloe on account of "English buccaneers," after King Maheyningerivo failed to deliver 1,000 slaves to him at Bombetoka Bay in 1741. ${ }^{104}$

\section{The Brak's instructions (11 October 1740)}

The Heren XVII provided the Cape government with its new Company ship, the Brak, in 1739. ${ }^{105}$ The Grevinden af Laurvigen, however, arrived at Table Bay in 1737 before the Brak's maiden voyage to Madagascar in 1740. The ship's first mate consulted the Sandberg's 1731 logbook at the house of an English sailor, John White, in the hope of purchasing slaves at Île Saint-

\footnotetext{
based capital, which includes the ownership of slaves, to liquid capital in the form of bonds, as per the central bank's charter.

100 IOR/E/I/17/ff.164-65v, 15 March 1726 and IOR/E/I/17 ff.205-05v: SSC applications for licenses from the EIC to trade at Madagascar.

${ }^{101}$ IOR/E/I/6 ff.275, 28 December 1715. The notorious Bristol slave trader William Heysham offered a 10 percent interest in outward bound cargo from Madagascar in return for an EIC license.

${ }_{102}$ Virginia Bever Platt, "The English East India Company and the Madagascar Slave Trade," The William and Mary Quarterly 26, no. 4 (October 1969), 553 and 555.

${ }^{103}$ Bialuschewski, "Pirates," 421 [cf. HA 4051, fols. 122-39, W.A. van der Stel to Heren XVII, 20 March 1705].

104 HA 4149, Brak (1741), 391-92. Slave-commissioner Hemmy recalled the murder of captain Jan de Kooning during the Barneveldt's voyage in 1719 and an English captain, named Cook, who was forced to flee Morondava and Young Owl on account of "robbers." ${ }^{105}$ C 110, 28 April 1739, 33-42.
} 
Marie: yet another example of the Cape's important role as a place where knowledge of the slave trade in the South-West Indian Ocean was exchanged between European slave traders. ${ }^{106}$ Charles Barrington was advised by a Swedish veteran of the Madagascar slave trade to buy slaves at Matatan and Fort Dauphin, though he had also been encouraged to trade at Morondava on the southwestern coast. ${ }^{107}$ The Brak's much-anticipated voyage, however, reopened the VOC's slave route from the Cape to Madagascar in 1741. Barrington also kept a copy of Drury's Madagascar in his cabin. ${ }^{108}$

The governor and Political Council, along with the Brak's captain, Jacobus van der Spil, studied the trade journals of the Voorhout (1676), Tamboer (1693), Soldaat (1696), Noordgouw (1701), Leijdsman (1715) and Herstelling (1732) ${ }^{109}$ in the formulation of the Brak's instructions. ${ }^{110}$ The Leijdsman's instructions, dated 15 June 1715, had ordered the expedition's "skipper," Pieter Knollendom, to study the Company's most recent slave voyages ("laatsten handel"); and the commissioners, Frappé and van der Lint, were instructed to purchase 300 slaves at St. Augustin's Bay, "Maratanga" and Maningare. ${ }^{111}$ Governor Chavonnes and his council had received news that the English slaver Clapham Galley had recently purchased 300 slaves on the west coast of the island. The Leijdsman returned to the Cape on Thursday 21 November 1715 with 200 slaves and the colonial government was eager to duplicate this with the Brak. The Brak's instructions, therefore, begin by exhorting the ship's officers to retrace the route taken by the Leijdsman and Herstelling, where "each ship mainly kept her visit during her trade to Cape St. Augustin, Fort Dauphin and at the Maningare river or New Massaly, before Fommetokke." ${ }^{112}$ The slave traders were instructed to consult the journals of the Soldaat, Leijdsman and Herstelling during the course of the expedition and to establish "friendship" with Malagasy kings and "potentates." They were ordered to purchase "lusty" males, between sixteen and twenty-four years of age, for employment on the Company's earthworks. The Political Council and VOC seafarers also studied the Brak's 1740 day register, after the vessel was forced to turn back on account of a strong current

\footnotetext{
106 DNA 446, "Charles Barrington, loose papers" (unpaginated).

107 Ellis, 423.

${ }^{108}$ Robert Drury, Madagascar; or Robert Drury's journal, during fifteen year's captivity on that island (London, 1729).

109 Thiebaut, "De Madagascar à Sumatra," 50. According to Thiebaut, the leaders of the Batavian-bound slave voyage of the Herstelling carried the trade journals of the Tamboer, Noordgouw and Leijdsman; while the leaders of the Binnenwijzend had copies of fifty years of VOC slave voyages in the master's cabin during their 1732 voyage.

110 HA 4144, Brak instructie (11 October 1740): 128-41. Jacobus van der Spil died during the Brak's 1742 voyage and was buried at Toliara.

${ }^{111}$ Armstrong and Westra, Slave Trade, 15. See also CA C 2341: 716-29, 718, 721 and 723. The Leijdsman's instructions are not as detailed as the Brak's instructions. 112 HA 4144, Brak instructie (11 October 1740), 129: "het Freguat De Lydsman in den jaar 1715 mitsgrs, het schip D'Herstelling $A^{\circ}$ : 1732 ook niet meer zyn bezogt geworden elk bodem in tegendeel haaren handel meest aan d'Caab St Aúgústyn, 'T Fort dauphin en in d'rivier Mannigaren of Nieúw Masaline voor Fommetokke."
} 
and stormy weather. ${ }^{113}$ The Brak retraced the course of the Leijdsman's journey to Toliara, Maningare and Bombetoka Bay on the Directors' orders in $1741 .{ }^{114}$ Otto Hemmy re-established the trade relationship that Frappé and van der Lint ${ }^{115}$ had forged with King Tokaf, in 1715, during his encounter with Tokaf's successor, Maheyningerivo, twenty-six years later. Hemmy conducted two further expeditions on the Brak, in 1742 and 1744, and purchased a total of 200 slaves during the three voyages. Copies of the Brak's instructions accompanied at least seven slave voyages (the Brak $(1741,1742$ and 1744), Drie Heuvelen (1753), ${ }^{116}$ Neptunus (1760) and Meermin (1762 and 1766)) and it can be argued that these instructions determined the Company's slave trading policy at Madagascar until the last VOC slave voyage to Mozambique in 1786 (which stopped at Madagascar for provisions of rice and beef). It can be argued, therefore, that the voyages of the Leijdsman and Brak (1741) were the foundation upon which the VOC built its slave trade from the Cape to Madagascar from 1715 to 1781 .

While the Brak's slave-commissioners established trade relations at Toliara and Bombetoka Bay, the French at Mauritius negotiated with the Portuguese to purchase slaves north of Cape Delgado, which led to the wholesale development of French slave markets at Quiloa, Querimba and Ibo on the Swahili coast. Otto Hemmy drafted a report on the slave trade at Toliara and Maravoay on 8 November 1741, which included advice from a French seafarer, Captain Seveille, who informed him that slaves were more readily available at Mozambique and that the "French fetched their best slaves from there," at forty Spanish reals for each adult male. ${ }^{117}$ Seveille told Hemmy that Mozambicans were not "thievish and murderous," like the Malagasy, but traders required licenses from the King of Portugal to trade at Mozambique. The French slave trade from the southeastern coast of Africa and Madagascar after the 1720s drew other nations to East Africa, in the way the English had

\footnotetext{
${ }^{113}$ C 115, Tuesday 27 December 1740, 129-37. The captain and first mate were later admonished by the Political Council.

114 HA 4149, Brak (1741), 3 July 1741, 262. Hemmy mentions how the Leijdsman's captain, Pieter Knollendom, had boarded a French slaver at Toliara with gifts of wine in 1715 . When Captain Godlob Silo arrived at Toliara he complained that the maps and journals in his possession did not indicate where to drop anchor.

${ }^{115}$ Armstrong and Westra, Slave Trade, 135n6. Van der Lint arrived at the Cape from Delft, Holland, in 1711. He served as assistant-commissioner on the Leijdsman. He resigned from the Company in October 1715.

${ }^{116}$ HA vol. 4193, Drie Heuvelen (1753) Skeepsjoernaal, 26 May to 17 December 1753 (hereafter "HA 4193, Drie Heuvelen (1753)"): 3116-176.

117 Ibid., 8 November 1741, 446: "Wy kommen ook met voor by deesen nog net Weinig te seggen dat my van den Franchen Capt. Seveille versttaan hebben dat mosambique vrÿ wat beter slaven úÿt leevert als dit Eÿland end at zy franschen altoos haare beste slaaven daar van daan haalen, zynde de prÿs 40 sp:rl:p ider mans en vrouwen door elkander maar dat seer omstigtig aldaar dient te werk gegeen te warden, dewÿl het een dieftagtige en moordagtige natie is Staande de portugueesen ook niemant aldaar handel toe als met permissive van den koning."
} 
done from 1670 to $1723 .{ }^{118}$ The French engaged in the slave trade north of Cape Delgado in the 1740s, and, at the end of the Seven Years War in 1763, governor-general Baltazar Manoel Perreira do Lago and the French colonial governor of the Îsle de France escalated the slave trade from Mozambique to the Mascarene islands to unprecedented levels. ${ }^{119}$ The VOC took advantage of the increased presence of French slavers at the Cape after 1773 through the provisioning and servicing of French vessels at Table Bay and the dispatching of Company slave voyages to the Swahili coast.

The instructions of the Schuylenburg (1752), Drie Heuvelen (1753) and Meermin (1766) contain verbatim extracts of the Brak's instructions of October $1740 .{ }^{120}$ The Drie Heuvelen was despatched on its voyage to Madagascar with a number of Dutch and English maps and sea-charts, but, more importantly, with the entire collection of significant VOC trade journals from 1676 to $1752 .{ }^{121}$ Captain Jacobus van der Spil's detailed maps of the bays of Toliara and Bombetoka - which describe suitable harbours, reefs, sources for fresh water and wood - were included in the Schuylenburg's register of papers. Hans Harmz, slave-commissioner of the Hector (1756), consulted a letter describing the bays of Madagascar, which the captain of the EIC's Delawar had drafted for Pieter Schoeneman, captain of the VOC's Naarstigheijd. ${ }^{122}$ Dirk Westerhof followed in Otto Hemmy's footsteps during the Drie Heuvelen's slave voyage to St. Augustin's Bay, Toliara and Anpandre. Westerhof, like Hemmy, was instructed to trade in the vicinity of Tolaria, then to head north to "New Massaly" (Maningare), on the opposite side of the island to Fort Dauphin. ${ }^{123}$ Johan Godfried Krause, ${ }^{124}$ like Hemmy, wrote detailed accounts of his dealings with Malagasy kings, princes and interpreters at Toliara, Bombetoka Bay and Matatan, on the east coast, during the slave voyages of the Neptunus (1760) and Meermin (1762). The captains and merchants of two English slavers, the Mercury and the Fly, informed the colonial government that slaves were available at Maningare in 1765. The Political Council responded to their report by outfitting the Meermin for a voyage to St. Augustin's Bay and Toliara, after the loss of nearly half the Company's slaves to disease, in April $1765 .{ }^{125}$ The VOC despatched nine

\footnotetext{
${ }^{118}$ Edward A. Alpers, "The French Slave Trade" and Ivory and Slaves in East Central Africa (Los Angeles: University of California, 1976). See also, Allen, European slave trading.

${ }^{119}$ Alpers, "The French Slave Trade," 97.

${ }^{120}$ C 2344, Drie Heuvelen instructie (1753), 63-69. See 1n12 above.

121 The Voorhout (1676), Tamboer (1694), Soldaat (1696), Noordgouw (1701), Leijdsman (1715), Herstelling (1732), the Brak's third voyage (1743) and Schuylenburg (two separate voyages dated 1752$)$.

122 CA C 2345, Hector (1756) "Register van papieren."

${ }^{123}$ Ibid., Drie Heuvelen (1753), Saturday 26 May 1753, 3118. "In teegenstelling" translates as "contrary" or "opposite."

${ }^{124}$ Sleigh and Westra, Meermin, 148n50. Krause was born in Lithuania. He arrived at the Cape in 1752 and was slave-commissioner of the Neptunus (1760) and Meermin (1762 and 1765-66). Krause was killed during the revolt aboard the Meermin on the morning of 18 February 1766.

125 Ibid., 51-52.
} 
voyages to Madagascar, in the aftermath of the Meermin's disastrous voyage, from 1766 to 1781. The Dutch sent the Zon, on the advice of French captains stopping at Table Bay, to East Africa in $1776 .{ }^{126}$ The inclusion of a lengthy report from the Zon's 1776 trade journal in the Political Council's 1777 resolutions reflects, yet again, the importance of trade journals in the planning and outfitting of VOC slave voyages at the Cape. ${ }^{127}$ The VOC signed a fiveyear contract with French mariner François Renier Duminy ${ }^{128}$ in 1781 on account of his experience of the Malagasy slave trade and East Africa and his network of contacts on either side of the Mozambique Channel. ${ }^{129}$ Duminy enabled the Dutch to transition their slave trade from Madagascar to East Africa during the 1780s.

\title{
Enslavement on the Malagasy coastline
}

\begin{abstract}
A 'closed' system of slavery
Markus Vink lists three broad categories of slaves in the VOC world: prisoners of war, slaves from debt-bondage and those who were kidnapped ie. people coerced into slavery. ${ }^{130}$ Hans Hägerdal has identified patterns of enslavement in the Timor region, in eastern Indonesia, during the seventeenth and eighteenth centuries based on Anthony Reid's model of 'open' and 'closed' systems of slavery. ${ }^{131}$ Whereas 'open' systems of slavery contain elements of inclusion within family structures, 'closed' systems of slavery maintain the 'outsider' status of enslaved peoples. While enslavement in Dutch Timor involved elements of both 'open' and 'closed' systems of slavery, counter to Vink's generalisation, the VOC slave trade at Madagascar was based almost wholly on 'closed' systems of enslavement, with people violently coerced into slavery through warfare and kidnapping. So much so, that the Reverend John Ovington made the following observation in 1689:
\end{abstract}

\footnotetext{
${ }^{126}$ C 155, Tuesday 6 May 1777, 214-34; and Ross, "Two Slaving Journals, Part 1" [Zon (1776-77)]: 308-09.

127 Ibid.

${ }^{128}$ François Renier Duminy (1747-1811) was the illegitimate son of a French Admiral who worked his way through the ranks of the French Compagne des Indes until its liquidation in 1765. Duminy was promoted to the rank of captain in the French private trade of the SouthWest Indian Ocean during the 1770s. He had vast experience of the South-West Indian Ocean slave trade by the time of his contract with the VOC in 1781.

129 See Andrew Duminy, François Renier Duminy (1747-1811): French Mariner and South African Pioneer (Pretoria: Protea Book House, 2005) and Loraine Maritz, "Die lewe en werk van François Renier Duminy, 1781-1811" (unpublished MA thesis, University of Stellenbosch, 1994). Andrew Duminy draws heavily on Maritz's research.

${ }^{130}$ Vink, "'The World's Oldest Trade'," 153.

${ }^{131}$ Hans Hägerdal, "Warfare, bestowal, purchase. Dutch acquisition of slaves in the world of eastern Indonesia, 1650-1800," at the international workshop "Slavery in the Indian Ocean World" Centre for Concurrences and Postcolonial Studies (Växjö-Kalmar) and International Institute for Social History (IISH, Amsterdam), Kalmar, 9 September 2017, hosted by Hans Hägerdal (University of Linnaeus, Sweden) and Matthias van Rossum (IISH).
} 
[Madagascar] is govern'd by several Kings, Independent, and Hostile to one another, designing continually upon each others Territories, being possessed with that restless Spirit of Ambition, which allows as little Ease to a Man's self, as it does security to his Innocent Neighbour. And here too, as well as in Africa, where we landed; they compute their Wealth by the Numbers of their Slaves, and wage their Wars upon their accounts. ${ }^{132}$

The European trading Companies and merchant traders, however, facilitated these methods of enslavement through what Hägerdal calls "strategic demands" made by the VOC to kings, fuelled by the sale of firearms, gunpowder, flints and lead.

The slave-commissioners of the Brak, Drie Heuvelen, Neptunus and Meermin purchased prisoners of war and abductees from the warring Sakalava, Betsimisaraka and other belligerents between 1741 and 1766. The sale of prisoners of war, however, extends to the earliest slave voyages outfitted at Cape. The personnel of ' $t$ Waterhoen reported that St. Augustin's Bay had been impoverished by continual wars as early as 1663 ; and the slavecommissioner of the Voorhout described the war between the king of St. Augustin's Bay, Andian Mananya, and King Lahifotsy of Boina, in 1671.133 Lady Anne Barnard, nominal first lady of the Cape at the turn of the nineteenth century, was told by the agent of the Irish slave trader Michael Hogan that the slaves she had seen in "pens" at Cape Town's foreshore had been purchased, "on the coast of Mosambique where this traffick [sic] took place that they kidnapd [sic] each other \& the strongest or the most powerful sold the weakest for what they could get." 134 Barnard's simplification of the enslavement of Mozambicans describes a situation that was greatly exacerbated during the nineteenth century in the South-West Indian Ocean region. The captain of the EIC's Swift was guaranteed a supply of " 100 to 150 or 160 or more slaves" on 21 March 1742, if he returned in May or June and remained at St. Augustin's Bay for two or three months, which suggests that he intended to forcefully procure slaves for the Englishman once the English had 'cruised' the east coast for enslaved people. ${ }^{135}$ On 30 November 1740, Stephen Cobham, commander of the EIC's Edgebaston, made the following entry in his "diary" on the southeastern coast of Madagascar: "Betwixt 12 and

\footnotetext{
132 John Ovington, A Voyage to Surat in the Year 1689 (London: Jacob Tonson, 1696), 104.

${ }^{133}$ Ellis, "Sovereigns," 418. See also Armstrong and Westra, The Slave Trade, 146n126. Armstrong and Westra explain how King Lahifotsy's eldest son, Timmelarivo (called "Trimmonongarevo" by Robert Drury), reigned over Toliara and nearby regions for over thirty years. Timmelarivo met the Leijdsman's party at Toliara in 1715.

${ }^{134}$ Margaret Lenta and Basil le Cordeur, eds., The Cape Diaries of Lady Anne Barnard, 1799-1800 2, Van Riebeeck Society Second Series no. 30 (Cape Town: Van Riebeeck Society, 1999), 69-70.

135 IOR/Logbook (L)/MAR/B/616A, Henry Watts's logbook for the EIC's Swift (1741-42) (unpaginated).
} 
one PM [sic], two canoas [sic] came to us from Tafass, ${ }^{136}$ with four quarters of a calf as a present from King Masheba, who sent his Linguist to acquaint us that he had been at War and had two hundred captives and three hundred head of cattle and hoped we could anchor there and take them off his hands." 137

Kidnapping was, by the time of the Meermin's voyage of 1766 , the preferred method of enslavement at Madagascar, and incidents like the abduction and sale of the landowner Massavana, by King Ramanrasse of Toliara, were commonplace. When the CJ interrogated Massavana during the trial following the loss of the Meermin, he explained how he had been sold into slavery:

I wore beautiful clothing, gold and silver on my body; and was asked by the King of Toliara to accompany him to the 'hooker' which brought me here, to view the vessel, which I did. The king had me bound up when we were halfway there, took the clothes, gold and silver off my body, and sold me to the vessel as a slave. ${ }^{138}$

Caravans of enslaved Malagasy were driven, in chains and stocks, from the interior to the coast, by the agents and representatives of kings and chieftains. The VOC slave-commissioner Constant van Nuldt Onkruidt reported in 1777 that the lands in the vicinity of Quiloa (northern Mozambique) were so barren that the inhabitants gave themselves over to the Sultan to be sold into slavery. ${ }^{139}$ Klara Boyer-Rossol's account of two enslaved Makua, Kalamba (Josef) and Tananan (Mikal), gives some indication, albeit at a later time, of coercion into slavery in the highlands of Mozambique. ${ }^{140}$ Boyer-Rossol's biographies, drawn from the writings of the Norwegian Christian missionary pastor, R.L. Aas, who was based in Morondava in the $1880 \mathrm{~s}$, describe how

\footnotetext{
136 The village of Tafass was situated on a river mouth between St. Lucia and Matatan on the southeastern coast of Madagascar.

137 IOR/L/MAR/622A Captain Stephen Cobham's "Commander's Journal" [countersigned by first mate Rob James] (hereafter "Edgebaston 1 (1740)"), Sunday 30 November, 50. See also IOR/L/MAR/622B Edgebaston Rob Veitch and Will Parks' "Deck Logg" (1740), "After noon" Sunday 30 November 1740, 93. The Drie Heuvelen arrived at the Cape was laden with a mixed cargo of 109 slaves and 11,971 kilograms of rice in 1753.

138 CA CJ 693: 173-203, Criminiele Proces-Stukken 1766, 121: Massavana: "Ant.

[Antwoord]: ik heb skoone kleeding, en silwer aan mijn lyf gehad; en bij door den kooning van Toulier bij gevraagt, om niethend en naar boord van den hoeker geveerd bij waarmede naar herweeards te gaan om dat voortuig te besten het qee ik gedaan hebbende, heft des koning mij op de heft van den weg, laaten vastmaaken mijn goud silwer en kleeding, das ik aan mijn lighaam had afgenoomen, en mij als doer aan dat voortuijg as slaaf verkogt." See also Sleigh and Westra, Meermin, 121.

139 Robert C.-H. Shell, "Slave Mortality on the Middle Passage to the Cape, 1688-1808," Quarterly Bulletin of the National Library of South Africa [Cape Town] 59, no. 3 (2005): 113-26, Shell, 103n30.

140 Klara Boyer-Rossol, "Makua Life Histories: Testimonies on Slavery and the Slave Trade in $19^{\text {th }}$ Century Madagascar," in A. Bellegamba, S.E. Greene, M.A. Klein, eds., African Voices on Slavery and the Slave Trade (Cambridge: Cambridge University Press, 2013), 466-80.
} 
enslaved people could be purchased three or four times after being tricked or coerced into slavery, like the young converts, Mikal and Josef.

\section{Letters of credential, welcoming rituals, trade prospects}

The outfitting of a Company slave voyage was costly and required the use of a ship, paid employees, provisions, ship's gear, timber, firewood, shackles, cooking equipment, specie, gifts and trade goods. The outfitting of a private slave voyage often necessitated the participation of multiple investors, ${ }^{141}$ although a corporation like the VOC had the capacity to build and outfit its own ships for the slave trade. The court records indicate that the VOC was more concerned with the loss of its ship than the loss of slaves and crew after a shipboard revolt on the Meermin in 1766. The loss of 'merchandise,' or property, was also an issue for the Political Council when dysentery claimed the lives of 200 enslaved Africans on François Duminy's voyages to Ibo in 1784 and 1785. The VOC modified its merchant ships - yachts, frigates, hoekers and brigantines - for the slave trade by constructing slave quarters for male and female slaves from partitions or bulkheads as they neared their destination. ${ }^{142}$ The Westerwijk, however, was purpose-built for the slave trade in 1685. ${ }^{143}$ In 1752, the Schuylenburg, which replaced the Brak as the Company's ship, was outfitted with a large kitchen on the main deck, large pots for the preparation of meals for slaves and crew and air vents in the hold. ${ }^{144}$ The Meermin's construction - which included slave quarters, crew areas and work spaces - was carefully designed for the embarkation of 300 slaves at Toliara and Maravoay in 1762 and 1766. ${ }^{145}$ Albert van Breugel's experience as junior merchant and "packhouse master," for example, suited him to the post of slave-commissioner for the Jambij in 1686, because of his experience managing warehouses and trade inventories. ${ }^{146}$ The slave ship was, after all, a floating factory, or warehouse, that was transformed into a prison for enslaved people as land came into view. ${ }^{147}$

The sight of a European ship or Arab dhow signaled the possibility of trade at Madagascar. Jacob de Bucquoi, previously employed as a mapmaker and draughtsman for the VOC at the Cape, described the arrival of the pirate ship, the Cassandra, at Maningare (Massaly River), on 15 August 1722. ${ }^{148}$ On

\footnotetext{
${ }^{141}$ See Robert Louis Stein, The French Slave Trade in the Eighteenth Century: An Old Regime Business (Madison: University of Wisconsin Press, 1979) for the outfitting of private slave voyages.

142 Shell, "Slave Mortality," 100.

${ }^{143}$ Ranjeva-Rabetafika, Baesjou and Everts, "Of Paper and Men," 49.

144 The Political Council requested a "flute-ship" from the Amsterdam chamber for the Madagascar slave trade in 1753.

145 Sleigh and Westra, Meermin, 117-18. Massavana's interrogation is the only known slave testimony from the Malagasy slave trade during the eighteenth century.

${ }^{146}$ C 18, 22 May 1686, 23-27. Andries de Man, who sat on the Political Council, was acting packhouse master during van Breugel's slave trading commission.

147 See Marcus Rediker, The Slave Ship: A Human History (London: John Murray, 2007).

148 Jakob de Bucquoi, Aanmerkelijke Ontmoetingen in de Zestien Jaarige Reize naar de Indiën (Haarlem: J. Bosch, 1744), 34. Du Bucquoi was employed as a cartographer at the
} 
seeing the pirates dropping anchor, fire a shot of cannon, and raise the black flag, the king's "coast guard" (strantwagter) "Lit a fire, which was followed by a second, then a third etc: the fires were followed deeper inland: thus giving the king knowledge in less than an hour that there was a ship on the Road [sic]." "149 James Barry encountered "a mightÿ great smoak [sic]" on the shore of a bay en route to Iongoeloe during the Phillip's slave voyage, on Wednesday 16 August $1682 .{ }^{150}$ His party reached Iongoeloe a week later, with Barry reporting, as recorded by the VOC clerk, that, "wee saw this nÿght smoakay fÿre, bÿ the inhabitants" and smoke to the north, the next day. ${ }^{151}$ Hendrik Frappé and Willem van der Lint heard from "Hollanders" from a VOC ship called the Overwinnaar that King Tokaf "had spent the whole night dancing and jumping at the sure news" of the Leijdsman's arrival at Maningare. ${ }^{152}$ Otto Hemmy's party was greeted with smoke signals when the Brak arrived there in August 1741 ${ }^{153}$; and the Meermin's officers tricked the slaves who had taken over their ship into thinking that they had been returned to Madagascar by alerting the landdrost of Stellenbosch and local militia at Soetendaal's Valley, near Cape Aghulas, to light bonfires on the beach via a message in a bottle. ${ }^{154}$ The Drie Heuvelen was approached by the canoe of one of the king of Morondava's subjects, Captain Jan, when the ship arrived there in August 1753. ${ }^{155}$ Captain Jan informed Dirk Westerhoff that the king had instructed him to board any ship or ships arriving at Morondava, and to ask them their business there. These meetings with Malagasy fishermen, villagers and royal subjects - like the "broker" (makelaar) Captain Jan typify first encounters between Europeans and Malagasy in the shallows of the coastline of Madagascar. It is worth mentioning here that the same party purchased slaves a week later at sea from men on canoes from the nearby village of Anpandre. ${ }^{156}$ European slave traders rewarded the services of lower-ranking traders or agents, like Jan, with gifts. The giving of gifts was an important means by which European slave traders advertised their wares on the island. Rafael Thiebaut has described the indispensable role of

\footnotetext{
Company's comptoir Fort Leidzhaamheit at Rio de la Goa from 1721 to 1722 . He was abducted by the pirate Oliver Levasseur 'la Buse' ('the vulture') in 1722 and spent fourteen years on the Cassandra.

149 Ibid.: "Hier door zyn, zy by den Inlander verkent waar op terstand een Konins

Strantwagter een fein doet van vuur, 't welk door een tweede, en derde enz: diper in 't land word nagedaan: dus heft de koning in min dan een uur kennisse dat 'er een shchip of de Reede is."

150 HA 4018, Phillip (1682), Wednesday 16 October 1682, 187.

151 Ibid., Wednesday 23 and Thursday 24 October 1682, 190.

152 Armstrong and Westra, Slave Trade, 89-91: Leijdsman's trade journal, Thursday 12 September 1715.

153 HA 4149, Brak (1741), 14 August 1741, 344.

154 The crew tricked the slaves who had taken over the vessel into thinking they had returned to Madagascar, an idea which was enforced by the arrival at a river (Soetendaal's river) and the lighting of three fires on the beach.

155 HA 4193, Drie Heuvelen (1753), Friday 3 August 1753, 3133.

156 Ibid., Saturday 11 August, 3144.
} 
intermediaries in the dealings between VOC slave-commissioners and Sakalava kings in his recent research on the Malagasy slave trade. ${ }^{157}$

Jane Hooper has highlighted the importance of 'welcoming ceremonies,' ritual banquets and the sharing of gifts in the fostering of commercial relationships at Madagascar which, she argues, were intimately tied to the provisioning trade. ${ }^{158}$ Trade commenced after formal introductions and the sharing of gifts: food and bullocks from Malagasy kings and princes; and arak, ${ }^{159}$ guns, gunpowder, flints, knives, cloth, beads, musical-boxes and mirrors from European slave-commissioners and supercargoes. Malagasy kings also offered their daughters and subordinate queens in ceremonial marriages to European slave traders as a gesture of goodwill during negotiations. The king of Iongoeloe, for example, 'married' his daughter to the slave trader Charles Barrington in 1738. King Ramanrasse warmly greeted the Brak's party at Toliara in 1741 with handshakes, in the presence of "hundreds of blacks with guns," while asking commissioner Otto Hemmy what his "message" ("bootschap") was. When the king's translator, Captain James, informed Hemmy that the king could understand English, Hemmy promptly read him the contents of his 'letters of credential' (credentiale brieven or "geloofsbrief"). The letters of credential explained that the Heren XVII wanted to re-establish the "old friendship" ("oudes vriendschap") they had maintained with his predecessors and to purchase slaves from him on a yearly basis. ${ }^{160}$ Kings and commissioners usually made mutual declarations of friendship and assurances of trade before inspecting their respective merchandise or negotiating the prices of slaves and provisions.

The ship's crew repaired their longboats and pinnaces, finished building the slaves' lodgings in the hold, and brought water and wood on board, while slave-commissioners and their assistants conducted negotiations on shore. De Bucquoi's party sent a delegation to purchase victuals from the king while some of the crew careened and caulked their upturned ship. The king met the captain and crew three days later with an army of 2,000 armed soldiers. He gave the men a bullock, and drank so much brandy that he appeared "like a drunk man in a comedy." 161 Otto Hemmy's trade journal recounts that the Arabs he had met on the northwestern coast of Madagascar had recommended the dispensation of arak as the "principle" means of negotiation during the slave trade. ${ }^{162}$ Hemmy plied King Ramanrasse with so much arak over a three

\footnotetext{
157 Thiebaut, "The Role of "Brokers," 62; and "Traite des esclaves," 393-99.

158 Hooper, Feeding Globalization, 2.

${ }^{159} \mathrm{C} 110$, Tuesday 25 April 1741, 69-107. The resolutiën explain how the strong alcoholic beverage arak - brewed from distilled red rice, sugar and coconut juice - was imported from Batavia to the Cape by the VOC for use in the slave trade.

160 HA 4149, Brak (1741), 5 July 1741, 269: "Hiet mij als doen vragen wat myne bootschap was daarop ek den Credentiaalen brief aan hem vertoonde" ("He asked me what my message was, thereon I showed him the Credential-letter").

${ }^{161}$ De Bucquoi, Aanmerkelijke Ontmoetingen, 34.

162 HA 4149, Brak (1741), 8 November 1741, Hemmy's summary of the slave trade (on leaving Toliara for the Cape), Friday 8 November 1741, 437.
} 
day period in Toliara, in July 1741, that the king was ill for three days. The king's drunkenness made Hemmy's negotiations very difficult (“lang werk"), though he eventually granted the merchant an audience, all the while sipping arak. ${ }^{163}$ At midday on July 25 "the king came with a frightening physiognomy," and, stamping his feet in a fit of drunken rage, fired a shot into the sand. The commies describes Ramanrasse with a glass of alcohol in one hand and three pipes of tobacco in the other, gifts from the Dutch, which he lit in succession as each expired. The Dutch gave away 234 flagons (out of a store of 1,224 "cans") of arak at Toliara; and plied King Maheyningerivo with arak at his palace in Maravoay some weeks later. ${ }^{164}$ The party continued to make gifts of arak while purchasing captives from the king and his men. Hemmy's party also gave arak to the "natives" (inlanders) who supplied them with food, water and wood at their camp on the beach. Captain Bagwell was cautioned by the Directors of the EIC to be careful of being stalled on the coast of Madagascar by the local kings, who liked brandy, but were not always forthcoming with slaves. ${ }^{165}$ The last instruction the captain of the Brak received was to maintain "Christian discipline" 166 during the voyage, which not only meant holding religious observances on Sundays, but to refrain from drinking the arak that was reserved for the trade. A little brandy or red wine, however, was rationed to slaves and crew to maintain immunity and morale on the return passage to Table Bay.

Once the slave ship dropped anchor at a bay or river mouth - like St. Augustin's, Toliara or Bombetoka Bay - the ship's officers and merchants erected barracoons and a 'factory' near the shore from bamboo, scrub and wood and planks from the hold. Sometimes slave traders paid Malagasy interpreters or local inhabitants to build their factories for them. The Brak's party built a temporary trading post with a kitchen, infirmary and storehouse - surrounded by a palisade - at Bombetoka Bay in 1742. ${ }^{167}$ The factory was usually guarded by a rotational watch under the captain, merchant, surgeon and other senior officers. While the Edgebaston was anchored at Fort Dauphin, the officers were requested to, "Send ashore six swivel Gunns with their proper Necessarys for the security of our Factory against one of the kings called Dean Pomet, who has lately been very troublesome to our Captain!"168 The captain, however, "brought the Queen of King Dean Manjeva with

\footnotetext{
163 Ibid., 438. Hemmy described how King Ramanrasse "would not leave his [calabash of arak] while there was a drop there" ("zÿ zullen deselve niet verlaten soo long daar een drop mis").

164 Ibid., 29 July 1741, 337. See also HA 4193, Drie Heuvelen (1753), 3122-176. Dirk Westerhof, who refused to trade barrels of arak for two slaves at Morondava River, distributed at least 671 cans of arak as gifts at Toliara, Morondava and Anpandre between Thursday 8 June and Friday 9 November 1753.

165 Hertford, Instructions (1730), 21.

166 "Christelijke discipline."

167 Ellis, "Sovereigns," 54.

${ }^{168}$ Edgebaston 1 (1740), Friday 7 November 1740, 86.
} 
several princes \& princesses to Dinner" that evening. ${ }^{169}$ European slave traders often showed their trading goods, or declared what goods they had on presentation of their credentiale brieven, to Malagasy kings; and Malagasy kings, in turn, showed their treasuries, armouries and slaves to their visitors. Newly arrived slaves were inspected by the ship's surgeon and slavecommissioner and held in barracoons or in the ship's hold, while the sale of slaves took place on the shore, or on ships and dhows, river mouths or the inland residences or encampments of kings. Otto Hemmy was taken nearly twenty kilometres to the town of Maravoay to meet King Maheyningerivo, in 1741. Slaves were transported to the slave ship once they had been purchased by the locals' canoes or the Company's longboats or pinnaces. Ironically, the slaves who overpowered the VOC's Meermin in 1766, tried to row to freedom in the ship's longboat at Soetendaal's Valley: one of the instruments of their enslavement. The EIC Directors instructed Captain George Bagwell of the Hertford, in 1730, not to stay too long in one place, because his party would be vulnerable to the predations of "European pirates" and "treacherous natives" who might force them to engage in trade. ${ }^{170}$ The threat of revolt or escape was greater near the coast, which is why the Brak's instructions ordered, in October 1740, that slaves be released from their shackles and manacles once land was out of sight. ${ }^{171}$ The officers of the Meermin paid dearly for not following this protocol in February 1766.

\section{Negotiations begin}

Negotiation for the sale of slaves began when 'welcoming ceremonies' and rituals ended. The VOC commies Hendrik Frappé and his assistant Willem van der Lint initiated negotiations in Madagascar during the Leijdsman's slave trade in 1715. ${ }^{172}$ They first encountered delegates of King Demonaij of Toliara on 27 July 1715. Their hosts led them, after perfunctory formalities, to a large tree about a mile and a half inland where "his black majesty" ("sijn swarte majestijt") sat with his retinue of four to five hundred men, women and children. ${ }^{173}$ The king's men were armed, and Frappé was warned by a Dutch castaway to be careful because the king had killed a Dutchman some years ago in a fit of anger. ${ }^{174}$ Frappé introduced himself, and reminded the king of his good relationship with the Company:

\footnotetext{
169 Ibid.

170 Hertford, Instructions (1730), 22.

171 See Eric Robert Taylor, If We Must Die: Shipboard Insurrections in the Era of the Atlantic Slave Trade (Baton Rouge: Louisiana University Press, 2006). Taylor makes extensive use of ships' journals in his monograph.

172 Armstrong and Westra, Slave Trade, 23.

173 Ibid., Hendrik Frappé [with additions by Willem van der Lint], “Journal of the main and most import events that occurred on the voyage from the Cape of Good Hope to the islands of Madagascar, Anjouan or elsewhere, as well as a description of the geography, people, livestock, fruits, crops, their decorations, customs regarding religion, etc.," Monday 29 July $1715,67$.

174 Ibid., Saturday 27 July 1715, 59. Demonaij killed one of the Schoonhouwen's sailors c. 1711.
} 
Then we also told him how pleased our Lord Directors were with the good reception our ships had enjoyed in previous years and that they had decided on a new mission to maintain the mutual understanding. ${ }^{175}$

King Demonaij recalled his father's good relationship with the Company and announced that he would supply the Dutch with slaves. He told the traders, who were now surrounded by 800 armed men, that he had sold slaves to the English, French and Portuguese in exchange for muskets, gunpowder, flints and lead. Demonaij settled on a final, lower price during the following day's negotiations, saying: "If you do not want to give this much I will keep my slaves and await the English, who will give me more."176 The Dutch purchased slaves from the king on Monday July 29, once they had settled on prices in a written contract with him. King Maheyningerivo of Boeny, who was no older than thirty-six years old (Otto Hemmy was thirty-one), made similar assurances to the German slave-commissioner in Maravoay, in 1741. The king offered elaborate homage to the insignia of four generations of his ancestors - King Tokaf, Tsimenata, Lahifotsy and "Meffere" - while hosting the Dutch trading-party at his palace. ${ }^{177} \mathrm{He}$ consecrated the signing of his contract with the Dutch during an elaborate religious ceremony before the same images of his ancestors, even though he was a muslim, a week later. Hendrik Frappé described how Maheyningerivo's father, Tokaf, had been "honoured and feared like a god" during the Leijdsman's voyage ${ }^{178}$ - an observation that was corroborated by Hemmy twenty-six years later. Stephen Ellis has explained that the bond between the Sakalava dynastic kings and their kinsmen awarded them a 'spiritual' status that often justified their enslavement of neighbouring peoples. ${ }^{179} \mathrm{Hemmy}$ reported that the French and English considered the king to be a rogue ("schelm") because he professed to be the friend and "father" of these nations, but was not often forthcoming in business. ${ }^{180}$

The Leijdsman reached Maningare on Wednesday 11 October 1715 and proceeded to Bombetoka River, where the slave-commissioners met King Tokaf. ${ }^{181}$ Tokaf was delighted with the Leijdsman's party, who had decorated their ship with flags and ribbons, fired a cannon salute, shot muskets in the air and arrived on the shore with a musical procession of drums, flutes and violins. ${ }^{182}$ Like Frappé, the English sailor Robert Drury, who was stranded on the island in the first decades of the eighteenth century, spoke highly of Tokaf.

\footnotetext{
175 Ibid., 61.

176 Ibid., Sunday 28 July 1715, 65.

177 HA 4149 Brak (1741), Wednesday 23 August 1741, 358.

${ }^{178}$ Armstrong and Westra, Slave Trade: Hendrik Frappé, "Short description of the westside of Madagascar or St. Laurens Island" ("Kort beschrijving van 't eijland Madagascar of S. Laurens aan de westsijde"), 129.

179 Ellis, "Sovereigns," 421.

180 HA 4149, Brak (1741), 8 November 1741, 438-39.

${ }^{181}$ Armstrong and Westra, Slave Trade, 89-107.

182 Ibid., 25.
} 
The Dutch negotiated with the king through his prime minister or "second voice" ("tweede stem"), Andian Simonalij, at the king's camp, which was half an hour from their factory by foot. The king and his wives were invited on board, where they dined and drank wine with the captain and slavecommissioners on Tuesday October 24. Simonalij told the slavecommissioners that the king's men had complained that their muskets were defective. Frappé and van der Lint, therefore, paid for the sale of 41 slaves with Spanish pieces of eight and gunpowder. Tokaf showed the merchants his armoury, and asked them to bring lighter guns with longer barrels next time. The Sakalava kings captured many Hova from the highland region of Amboalambo with guns supplied to them by the Europeans. ${ }^{183}$ The slave trade at Madagascar was, as we have seen, predicated on guns, warfare and kidnapping.

The arrival of European slave traders on the Malagasy coastline was communicated inland by fires, coast guards, brokers and messengers. VOC slave traders frequently made contact with fishermen and petty officials of Malagasy kings, as well as European and Arab slave traders, before sending their officers to shore. First contacts with Malagasy kings were usually made on shore or aboard the Company's ships. Introductory encounters included salutes and greetings, the presentation of letters of endorsement and ceremonious welcoming rituals (the sharing of gifts, food and alcohol). These encounters included the mutual inspection of trade goods and slaves, as well as assurances of trade. Negotiations over the number and prices of slaves ensued, which culminated in written contracts or verbal agreements between parties. VOC personnel worked within the limits of their instructions and their letters of credential or introduction legitimised them as bona fide representatives of the Directors of the Company in the eyes of Malagasy kings.

\section{Conclusion}

The VOC's slave voyages in the South-West Indian Ocean from 1663 to 1781 began with a refreshment stop at Mauritius (until 1715), the purchase of slaves on the west coast of Madagascar, provisioning stops at Anjouan, and a last attempt, on the return voyage, to buy slaves at Rio de la Goa. Simon van der Stel and his personnel developed the slave trade from the Cape of Good Hope to Madagascar with the help of English trade journals, maps and counsel from 1679 to 1698 . The Company further developed its slave trade by consulting records of its own voyages after 1700. The VOC was influenced by English slave traders until the mid-1720s and utilised English maps on their voyages until the 1780s. The Company had forty years of slave trading experience on the northwestern coast of Madagascar to draw on by the time of the

${ }^{183}$ Ellis, "Sovereigns," 414; HA 4149 Brak (1741), Sunday 27 August 1741, 367. Ellis recounts that King Maheyningerivo had told Hemmy he had sent his "people" to Amboalambo ("d'Ambolúmmers"). 
Leijdsman's voyage in 1715. Captain Jacobus van der Spil and slavecommissioner Otto Hemmy successfully revived the Leijdsman's trade relations with the kings of Toliara and Maravoay during the Brak's first expedition in 1741. This article charts the development of the VOC slave trade from the Cape of Good Hope to Madagascar during the seventeenth and eighteenth centuries through navigation, inquiry, diplomacy and trade. It argues that the two landmark voyages of the Leijdsman and Brak were crucial in the establishment of VOC slave trading policy on the island of Madagascar from 1741 to 1781 . This article further describes typical first contacts between VOC slave traders and Malagasy kings and their representatives on the coastline of Madagascar during the eighteenth century.

\section{Appendix: VOC instructions (instructiën or instructies (Afrikaans)) and ships' journals (skeepsjoernale or joernale) for the Company's slave voyages from the Cape to Madagascar, 1658-1786}

\section{Instructions (instructiën):}

"Instructions" ("Instructies"), "Register of Papers" ("Register van papieren") and crew lists for the majority of the VOC's slave voyages to Madagascar (and the east coast of Africa) are housted in the National Archives of South Africa in Cape Town (CA) Political Council (Politieke Raad) (C) Series, CA C 2333, Maria (1661); CA C 2339, Westerwijk and Jambij; CA C 2340, Jambij (1686) and Baren and Jambij (1687), Tamboer (1694), Noordgouw (1701, 1702 and 1703) and Ter Aa (1705, 1706 and 1707); CA C 2341, Leijdsman (1715); CA C 2344, Drie Heuvelen (1753), Schuylenburg (1755) and Hector (1756); CA C 2345, Hector (1758 and 1759), Neptunus (1760 and 1762) and Meermin (1762 and 1763); Voorhout (1767); CA C 2346, Zon (1775 and 1776) and Jachtrust (1777); CA C 2347, Jachtrust (1779, 1780 and 1781) (mentions François Renier Duminy's voyage to Ceylon); and, CA C 2348, Meermin (1780, 1784 and 1785). CA C 2350-53 contain "memorials and instructions" relevant to Duminy, but not his slave trading activities. Rafael Thiebaut made CA C 2361 available to me, which contains a comprehensive list of instructions and logbooks for the VOC era - "Register of Instructions ("Register op Instructies"), 1657-1784": 1-139; "Inventory of Day Registers or Journals of sea voyages and land journeys made, also reports of wrecked vessels and other matters describing lands and coasts, 16551770"; and CA C 2243 contains a list of VOC slave voyages which was compiled on the order of the first British governor of the Cape Earl George Macartney in 1798. 


\section{Ships' journals or day registers, dagregisters or skeepsjoernale:}

Nationaal Archief of the Netherlands in Den Haag (HA) VOC Series, Access Number 1.04.02, Overgekomen brieven en papieren van de Kaap de Goede Hoop aan de Heeren XVII en de kamer Amsterdam ("Letters and papers despatched from the Cape of Good Hope to the Seventeen Lords and the Amsterdam chamber" (1651-1792)). The HA 1.04.02 Overgekomen brieven, which includes ships' journals and instructions, is available online at https://www.nationaalarchief.nl/onderzoeken/archief/1.04.02. Here is a list of ship's journals at Den Haag, the Cape and the National Library of South Africa (Cape Town): 't Waterhoen I (1663) HA 3998 (with instructie); ' $t$ Waterhoen II (1664-65) CA C 2243; Pijl \& Boog (1672) HA 4008 (with instructie); Voorhout I (1676) HA 4012 (with instructie for Voorhout and Tulp CA C2338); Voorhout II (1677) HA 4013; Jambij (1686) HA 4023; Tamboer (1694) HA 1544; Soldaat (1696) HA 5072 (with instructie); Peter \& Paul (1699) HA 4043; Noordgouw I (1701) HA 4047; Noordgouw II HA 4047; Ter Aa (1706) HA 4057; Leijdsman (1715) HA 4074 and HA 4052 and National Library of South Africa (NLSA) MSD 3 and 10 (with instructiën); Snuffelaar \& Zeepost (1732) HA 4118; Brak I (1741) HA 4149 (Brak instructie (1740) HA 4144); Brak II (1742) HA 4157; Brak III (1743); Schuylenburg (1752-53) HA 4187; Drie Heuvelen (May to December 1753) HA 4188; Neptunus (1760) CA C 2250-2251; Meermin (1763) HA 4229; Meermin (1765-66) HA 4245; Meermin (1766) HA 4241; Zon I (1770) HA 4257 and CA C 2251; Snelheid (1771) HA 4261 and CA C 2252; Snelheid (1773-74) HA 4273 and CA C 2253; Zon II (1774-75) HA 4261 and CA C 2254; Zon III (1775-76) HA 4281 and CA C 2254 and CA C 2256; Zon IV (Jan 1777) HA 4283 and CA C 2256; Jachtrust I (Apr 1777) HA 4283; Jachtrust II (1777-78) CA C 2257; Jachtrust III (1781) HA 4249 and CA C 2280; Meermin I (July 1784 to January 1785) HA 4289; and, Meermin \& Meeuwtjie II (June 1785 to February 1786) CA C 2066 and National Library of South Africa (NLSA), Cape Town, Nöthling Collection MSB 361.

\section{Bibliography}

\section{PRIMARY SOURCES}

\section{CAPE ARCHIVES DEPOT, CAPE TOWN (CA)}

A Accessions

A 455 BP 12 (0) W.S. van Ryneveldt, "Replies to the Questions on the Importation etc. of Slaves into the Colony; Proposed by His Excellency the Earl of Macartney etc., etc., dated 29 November 1797 (preserved to the Cape Archives by G.W.A. Mears, "the original mss. destroyed by fire")." A 455, Dundas-Melville Papers, "Macartney's Description of the Cape Colony." C Council of Policy 
C 325 Untitled. Extracts from Letters from Simon van der Stel and the Political Council to the VOC Directors in Amsterdam, dated 1682: 44-81; and VOC Directors (Amsterdam chamber) to Simon van der Stel and the Political Council (Cape of Good Hope), 1 January 1682: 7-8.

C 2243 "Journals kept on board the different ships on their several voyages \& expeditions since the year 1615 till 1793" [English copy of C2244].

C 2244 "Register op instructies, 1657-1784" ["Register of instructions, 16571784"]: 1-139.

C 2344 Drie Heuvelen (1753) Instructie.

C 2361 "Skeeps-en ander joernale": 69-87.

C 2251 Neptunus (1760) "Skeeps- en ander joernale. Dagregister gehou aan boord de Neptunus, 1760 Nov 24 - 1761 Feb 14." (Johan Godfried Krause).

CJ Council of Justice

CJ 693 Criminiele Proces-Stuken, 1766: 174-203.

\section{BRITISH LIBRARY, LONDON (BL)}

India Office Records (IOR) Maritime (MAR) Series:

IOR/MAR/B/106 "Orders and Instructions Given by the Court of Directors of the United Company of Merchants of England Trading to the East Indies to Captain George Bagwell, Mr Richard Taylor and Mr William Oaker" (26 October 1730): 17-23.

IOR B 154 f.22, "Sloane Collection no. 4044," Woodes Rogers to Sir Hans Sloane, 7 May 1716.

IOR/L/MAR/B/622A Edgebaston “Commander's Journal” (Stephen Cobham) (20 December 1739 - 7 August 1742): 1-131 [double-sided pages].

IOR/L/MAR/B/622B Edgebaston Rob Veitch and Will Parks's "Deck log” (1740-41): 80-102.

IOR/L/MAR/B/164C Onslow (Captain Balchen) (1740-41).

IOR/L/MAR/B616A Swift logbook (1741-42).

IOR India Office EIC Court Director's Minutes (D) and (E) Series

IOR/D/93 f.511 Minutes of the EIC Directors.

IOR/E/I/17/ff.164-65v 15 March 1726 South Sea Company (hereafter SSC) application for licenses from the EIC Directors.

IOR/E/I/17 ff.205v SSC application for a license from the EIC Directors.

IOR/E/I/6 ff.275 28 December 1715, William Heysham application for a license from the EIC Directors.

\section{DANISH NATIONAL ARCHIVE (RIGSARKIVET), COPENHAGEN}

446 "Het Vestindisk-Guineisk kompagni, Charles Barrington," 218 1737-1742 and "Charles Barrington's trade journals, charter party, ship logbooks and trade journals," 220, no. 2 1737-1738 (mainly unpaginated loose papers and Charles Barrington "Logbook 1": 1-90 [single pages]) and 221, no. 3 (c.1725-38) (loose papers). 
ARCHIVE DEN HAAG (HA)

VOC Series, Access Number 1.04.02 "Inventaris van het archief van de Verenigde Oost-Indische Compagnie (VOC)," 1602-1795, Deel I/E.5.b: Overgekomen brieven en papieren uit Kaap de Goede Hoop aan de Heeren XVII en de kamer Amsterdam (https://www.nationaalarchief.nl/onderzoeken/archief/1.04.02.).

HA 1639 "Cabo de Goede Hoop a ${ }^{\circ}$ 1700," Letter from Willem Adriaan van der Stel (Governor of the Cape) and Willem van Outhoorn (Governor-General of Batavia) [concerning the English slaver the Harwich], 22 March 1700: 37-38.

HA 4018 The Phillip (1682) (James Barry), "Extract úÿt seeker Engelse dagregister gehoúden bÿ James Barree supercargo: op 't Engelse schip de fillip [2 April 1682] naar 't Eÿlandt Madagascar Streeks": 174-95 [doublesided pages].

HA 4144 Brak (1740) Instructie: 128-41.

HA 4149 Brak (1740) Skeepsjoernaal (Otto Hemmy) (4 May to 25 December 1741): 241-458 [double-sided pages].

HA 4193 Drie Heuvelen (1753) Skeepsjoernaal (Dirk Westerhoff) (26 May to 17 December 1753): 3116-176 [double-sided pages].

ROYAL MUSEUMS GREENWICH, CAIRD LIBRARY, LONDON

LUB/39/28 Lubbock, Basil, "List of English East India Company Ships."

\section{BRENTHURST LIBRARY, OPPENHEIMER COLLECTION, JOHANNESBURG}

MS 61/3 Barrow, Sir John, Sketches of the Political and Commercial History of the Cape of Good Hope (1 December 1796).

\section{PUBLISHED PRIMARY SOURCES}

TANAP Resolusies of the Council of Policy http://databases.tanap.net/resolusies/

(C) (Retrieved 1 October 2020)

C 16 Minutes 13 December 1682: 42-44.

C 18 Minutes 22 May 1686: 23-27.

C 18 Minutes 10 February 1687: 112-15.

C 33 Minutes 21 May 1715: 68-78.

C 89 Minutes 25 March 1732: 72-90.

C 110 Minutes 25 April 1741: 69-70.

C 115 Minutes 27 December 1740: 129-37.

C 155 Minutes 6 May 1777: 214-34. 


\section{PRINTED CONTEMPORARY WRITINGS}

De Bucquoi, Jakob, Aanmerkelijke Ontmoetingen in de Zestien Jaarige Reize naar de Indiën [Remarkable Encounters in the Sixteen Year Journey to the Indies] (Haarlem: J.Bosch, 1744).

Drury, Robert, Madagascar; or Robert Drury's journal, during fifteen year's captivity on that island (London, 1729).

Van Dam, Pieter, Beschryvinge van de Oostindische Compagnie, XLVII, "orders van de XVII voor den slavenhandel," Bijlage 2 (Amsterdam, 1701): 668670 .

Ovington, John, A Voyage to Suratt in the Year 1689 (London: Jacob Tonson, 1696).

\section{SECONDARY SOURCES}

\section{BOOKS}

Allen, Richard B., European Slave Trading in the Indian Ocean, 1500-1850 (Athens: Ohio University Press, 2015).

Alpers, Edward A., Ivory and Slaves in East Central Africa (Los Angeles: University of California, 1979).

Armstrong, James and Westra, Piet, Slave Trade with Madagascar: The journals of the Cape slaver Leijdsman, 1715 (Cape Town: Africana Press, 2006).

Barendse, R.J., Arabian Seas 1700-1763, vol.3, "Men and Merchandise" (Leiden: Brill, 2009).

Bōeseken, Anna, Slaves and free blacks at the Cape, 1658-1700 (Cape Town: Tafelberg, 1977).

Boucher, Maurice, The Cape of Good Hope and Foreign Contacts 1735-1750 (Pretoria: University of South Africa, 1985).

Capela, José, O Tráfico de Escravos nos Portos de Moçambique, 1733-1904 (Porto: Ediçōes Afrontamento, 2002).

Cordingly, David, Spanish Gold: Captain Woodes Rogers and the Pirates of the Caribbean (London: Bloomsbury Publishing, 2011).

Duminy, Andrew, François Renier Duminy (1747-1811): French Mariner and South African Pioneer (Pretoria: Protea Book House, 2005).

Elphick, R. and Giliomee, H., eds., The Shaping of South African Society, 16521840, $2^{\text {nd }}$ ed. (Cape Town: Maskew Miller Longman, 1989)

Ferguson, Niall, The Ascent of Money: A Financial History of the World (London: Penguin Books, 2009).

Filliot, Jean-Marie, Les Traite des Esclaves vers les Mascareignes au XVIIIe Siècle (Paris: ORSTOM, 1973).

Florentino, Manolo, Em Costas Negras: Uma história do tráfico de escravos entra a África e o Rio de Janeiro (séculos XVIIIe XIX)(Companhia Das Letras: São Paulo, 1997).

Grandidier, Alfred and Guillaume, Collections des ouvrages anciens concernant Madagascar, 9 vols. (Paris: Comité de Madagascar, 1903-1920).

Haalmeijer, Hans, Pinassen, Fluiten en Galjassen: Zeilschepen van de Lage Landen-Kustvaart en Grote Vaart (Alkmaar, Holland: De Alk bv., 2009). 
Hooper, Jane, Feeding Globalization: Madagascar and the Provisioning Trade, 1600-1800 (Athens: Ohio University Press, 2017).

Klein, Herbert S., The Middle Passage: Comparative Studies in the Atlantic Slave Trade (New Jersey: Princeton University Press, 1978).

Krüger, D.W. and Beyers, C.J., eds., Dictionary of South African Biography, vol. 3 (Cape Town: Tafelberg, 1977).

Lenta, Margaret and Le Cordeur, Basil, eds., The Cape Diaries of Lady Anne Barnard, 1799-1800 2, Van Riebeeck Society Second Series no. 30 (Cape Town: Van Riebeeck Society, 1999).

Machado, Pedro, Ocean of Trade: South Asian Merchants, Africa and the Indian Ocean, c.1750-1850 (Cambridge: Cambridge University Press, 2014).

O’Malley, Gregory E., Final Passages: The Intercolonial Slave Trade of British America, 1619-1807 (Williamsburg, Virginia: University of North Carolina Press, 2014).

Pettigrew, William A., Freedom's Debt: The Royal African Company and the Pollitics of the Atlantic Slave Trade, 1672-1752 (Williamsburg, Virginia: University of North Carolina Press, 2013).

Rediker, Marcus, The Slave Ship: A Human History (London: John Murray, 2007).

Rogoziński, Jan, Honor Among Thieves: Captain Kidd, Henry Every, and the Pirate Democracy in the Indian Ocean (Mechanicsburg, Pennsylvania: Stackpole Books, 2000).

Schoeman, Karel, Early Slavery at the Cape of Good Hope, 1652-1717 (Pretoria: Protea Book House, 2007).

. Portrait of a Slave Society: The Cape of Good Hope, 1717-1793 (Pretoria: Protea Book House, 2012).

Shell, Robert Carl-Heinz, Children of Bondage: A Social History of the Slave Society at the Cape of Good Hope, 1652-1838 (Johannesburg: Witwatersrand University Press, 1994).

Sleigh, Dan, Die buiteposte: VOC-buiteposte onder die Kaapse bestuur 16521795 (Pretoria, HAUM 2004).

Sleigh, Dan and Westra, Piet, The Taking of the Slaver Meermin 1766 (Cape Town: Africana Publishing, 2013).

Stein, Robert Louis, The French Slave Trade in the Eighteenth Century: An Old Regime Business (Madison: University of Wisconsin Press, 1979).

Taylor, Eric Robert, If We Must Die: Shipboard Insurrections in the Era of the Atlantic Slave Trade (Baton Rouge: Louisiana State University Press, 2006).

Van Bart, Marthinus, Kaap Van Slawe: Die Britse slawebedryf van 1562 tot 1910: Met spesiale verwysing na die Kaap die Goeie Hoop vanaf 1680 (Cape Town: Historical Media, 2012).

Worden, Nigel, Slavery in Dutch South Africa (Cambridge: Cambridge University Press, 1985). 


\section{ARTICLES AND CHAPTERS IN BOOKS}

Alexander, Andrew, "Shipboard Slave Uprisings on the Malagasy Coast. The "Meermin" (1766) and "De Zon" (1775)," Kronos: Journal of Cape History [Cape Town] 33 (November 2007): 84-111.

. "Negotiation, trade and the rituals of encounter: an examination of the slave trading voyage of De Zon, 1775-1776," Itinerario 31, no. 3: 39-58.

Allen, Richard B., "A traffic of several nations: the Mauritian slave trade, 17211835," in V. Teelock and E.A. Alpers, eds., History, Memory and Identity (Mauritius: University of Mauritius Press, 2001), 157-77.

. "The Mascarene Slave-Trade and Labour Migration in the Indian Ocean during the Eighteenth and Nineteenth Centuries," in Gwyn Campbell, ed., The Structure of Slavery in the Indian Ocean, Africa and Asia (New York: Routledge, 2006), 33-50.

. "The constant demand of the French: The Mascarene Slave Trade and the World of the Indian Ocean and Atlantic during the Eighteenth and Nineteenth Centuries," Journal of African History 49, no. 1 (2008): 43-73.

Alpers, Edward A., "The French Slave Trade in East Africa (1721-1810)," Cahiers d'etudes africaines 10, no. 37 (1970): 80-120.

Armstrong, James, "Madagascar and the Slave Trade in the Seventeenth Century," Omaly Sy Anio (Hier et aujour d'hui) [Madagascar] nos. 17-20 (1983-84): 211-32.

Armstrong and Worden, "The Slaves, 1652-1795," in Elphick, R and Giliomee, H, eds., The Shaping of South African Society, 1652-1820, $2^{\text {nd }}$ ed. (Cape Town: Maskew Miller Longman, 1989), 109-68.

Bialuschewski, Arne, "Pirates, Slavers and the Indigenous Population in Madagascar, c.1690-1715," International Journal of African Historical Studies 38, no. 3 (Boston University African Studies Centre, 2005): 40125.

Boucher, Maurice, "The Cape and foreign shipping, 1714-23" South African Historical Journal 6, no. 1 (November 1974): 3-29.

. "The Voyage of a Cape Slaver in 1742," Historia [Pretoria] 24, no. 1 (1979): 50-58.

. "An Unexpected Caller: Charles Barrington at the Cape in 1737," South African Historical Journal 13 (1981): 20-35.

Boyer-Rossol, Klara, "Makua Life Histories: Testimonies on Slavery and the Slave Trade in $19^{\text {th }}$ Century Madagascar," in Bellagamba, A., Greene S.E. and Klein, M.A., eds., African Voices on Slavery and the Slave Trade (Cambridge: Cambridge University Press, 2013), 466-80.

Debien, G., "Le Journal de traite de la Licorne au Mozambique, 1787-1788," in Estival, R. and Braudel, F., eds., Etudes africaines offertes à Henri Brunschwig (Paris: EHESS, 1982) 91-116.

Ellis, Stephen and Randrianja, S., "Les archives de Compagnie néerlandaise des Indes orientales et l'histoire de Madagascar. L'expedition du navire de la Verenigde Oostindische Compagnie (V.O.C.) Le Schuylenburg Septembre 1752," in I. Rakoto, ed., La route des esclaves (Paris: Harmattan, 2000), 47-73. 
Ellis, Stephen, "The history of sovereigns in Madagascar: new light from old sources," in Nativel, Didier and Rajaonah V., Faranirina, eds., Madagascar revisitée: en voyages avec Françoise Raison-Jourde (Karthala: Paris, 2009), 405-31.

Eltis, David and Hooper, Jane L., "The Indian Ocean in Transatlantic Slavery," Slavery and Abolition 34, no. 3 (2013): 353-75.

Hardyman, J.T., "The Madagascar slave trade to the Americas (1632-1830)," Studia Revista Semestria 11 (January 1963): 501-21.

Harries, Patrick, “'The Hobgoblins of the Middle Passage': the Cape of Good Hope and the Transatlantic Slave Trade," in Schmieder, Ulrike, FülbergStoberg, Katja, Zeuskem, Michael, eds., The End of Slavery in Africa and the Americas: a comparative approach (Munster: LIT Verlag, 2011), 2750 .

. "Middle Passages of the Southwest Indian Ocean: A Century of Forced Immigration from Africa to the Cape of Good Hope," The Journal of African History 5, no. 2 (July 2014): 173-90.

. "Mozambique Island, Cape Town and the Organisation of the Slave Trade in the South-West Indian Ocean, c.1797-1807," Journal of Southern African Studies 42, no. 3 (2016): 409-27.

Klein, Herbert S., "The Trade in African slaves to Rio de Janeiro, 1795-1811: Estimates of mortality and patterns of voyages," Journal of African History 10, no. 4, 533-49.

Larson, Pier M., "Enslaved Malagasy and 'Le Travail de la Parole' in the PreRevolutionary Mascarenes," Journal of African History 48, no. 3 (2007): 457-479.

Machado, Pedro, “A Forgotten Corner of the Indian Ocean: Gujarati Merchants, Portuguese India and the Mozambique Slave-Trade, c.1730-1830," in Slavery \& Abolition 24, no. 2 (2003): 17-32.

Platt, Virginia Bever, "The English East India Company and the Madagascar Slave Trade," The William and Mary Quarterly 26, no. 4 (October 1969): 548-77.

Ranjeva-Rabetafika, Baesjou, René and Everts, Natalie, “Of Paper and Men: a note on the Archives of the VOC as a source for the history of Madagascar," Itinerario 24, no. 1 (2000): 45-67.

Reidy, Michael Charles, "Book review of Dan Sleigh and Piet Westra's, The Taking of the Slaver Meermin, 1766," Bulletin of the National Library of South Africa 68, no. 1 (2014): 119-22.

Ross, Robert, "The Dutch on the Swahili Coast, 1776-1778: Two Slaving Journals, Part 1," The International Journal of African Historical Studies 19, no. 2 (Boston University African Studies Centre, 1986): 305-60.

. "The Dutch on the Swahili Coast, 1776-1778: Two Slaving Journals, Part 2," The International Journal of African Historical Studies 9, no. 3 (1986): 479-506.

. "The Last Years of the Slave Trade to the Cape Colony," in ClarenceSmith, W.G., ed., The Economics of the Indian Ocean Slave Trade in the Nineteenth Century (London: F. Cass, 1989), 209-20. 
Shell, Robert Carl-Heinz, "The Twinning of Maputo and Cape Town: The Early Mozambican Slave Trade to the Slave Lodge: 1677-1731," Quarterly Bulletin of the National Library of South Africa [Cape Town] 55, no. 3 (2001): 114-20.

. "Slave Mortality on the Middle Passage to the Cape, 1688-1808," Quarterly Bulletin of the National Library of South Africa [Cape Town] 59, no. 3 (2005): 113-26.

Van Rensburg, Andre Martinus, "The secret modus operandi used to obtain slaves from Guinea for the Cape: the ship Hasselt, 1658," Familia 38, no. 2 (2001): 78-92.

Vernet, Thomas, "Slave trade and slavery on the Swahili coast (1500-1750)," in Mirzai B.A., Montana I.M. and Lovejoy, P., eds., Slavery, Islam and Diaspora, (African World Press, 2009), 37-76.

Vink, Markus, “'The World's Oldest Trade.' Dutch Slavery and the Slave Trade in the Indian Ocean in the Seventeenth Century,' Journal of World History 14, no. 7 (June 2003): 131-77.

Worden, Nigel Anthony, "Slavery and amnesia: towards a recovery of Malagasy heritage in representations of Cape slavery," in Ignace Rakoto, ed., L'esclavage à Madagascar: Aspects Historiques et Résurgences Contemporaires (Antananarivo: Institut de Civilisations - Musée d'Art et d'Archéologie, 1997): 51-63.

. "Indian Ocean Slavery and its demise in the Cape Colony," in Campbell, Gwyn, ed., Abolition and its Aftermath in Indian Ocean Africa and Asia, (New York: Routledge, 2005), 29-49.

. "Indian Ocean Slaves in Cape Town, 1695-1807," Journal of Southern African Studies 42, no. 3 (2016): 389-408.

\section{THESES AND UNPUBLISHED PAPERS}

Hägerdal, Hans, "Slaves and slave trade in the Timor area: Between indigenous structures and external impact," (unpublished paper, "Slave Trade in the Indian Ocean and Indonesian Archipelago Worlds," presented at the International Institute of Social History (IISH), Amsterdam, 10-11 November 2016) (convenors, Dr Matthias van Rossum and Dr Titas Chakraborty).

Maritz, Loraine, "Die lewe en werk van François Renier Duminy, 1781-1811," (unpublished MA thesis, University of Stellenbosch, 1994).

Ravell, James J., "The VOC Slave Trade Between Cape Town and Madagascar" (Leiden, 1978).

Reidy, Michael Charles, "Captive experience aboard VOC slave ships during the Indian Ocean Middle Passage in the $18^{\text {th }}$ century," (unpublished paper, "The Southwest Indian Ocean - and the slave trade," History Department, University of Basel, Switzerland, 5 December 2014 (convenor, Dr Patrick Harries)).

Thiebaut, Rafael, "Traites des esclaves et commerce néerlandais et français á Madagascar (XVIIe-XVIIIe siécles)," (unpublished PhD. Thesis, Sorbonne University Paris and Free University Amsterdam, 2017). 


\section{DIGITAL SECONDARY SOURCES}

Shell, Robert C.-H., ed., From Diaspora to Diorama: A Guide to the Old Slave Lodge (Cape Town: Nagpro, 2013).

Thiebaut, Rafael, "De Madagascar à Sumatra: une route négrière peu commune. Le voyage du navire Binnenwijzend de la VOC en 1732," Afriques [En ligne], uploaded on 21 December 2015, consulted 16 March 2021. URL: http://journals.openedition.org/afriques/1805; DOI: https://doi.org/2010. 20204000/afriques. 1805

. "The Role of "Brokers" in the Dutch Slave Trade in Madagascar in the Eighteenth Century," in Preben Kaarsholm, Manoel João Ramos and Iain Walker, eds., Fluid Networks and Hegemonic Powers in the West Indian Ocean (Lisbon: Centro de Estudos Internacios do Instituto de Lisboa, 2017): 37-64. E-book. 